Article

\title{
Population Characteristics of the Mid-Littoral Chthamalid Barnacle C. stellatus (Poli, 1791) in Eastern Mediterranean (Central Greece)
}

\author{
Dimitris Klaoudatos *, Zoi Kotsiri, Nikos Neofitou, Alexios Lolas (1) and Dimitris Vafidis \\ Department of Ichthyology and Aquatic Environment, School of Agriculture Sciences, University of Thessaly, \\ 38446 Volos, Greece; zkotsiri@uth.gr (Z.K.); nikneof@uth.gr (N.N.); allolas@uth.gr (A.L.); dvafidis@uth.gr (D.V.) \\ * Correspondence: dklaoud@uth.gr
}

Received: 14 October 2020; Accepted: 23 November 2020; Published: 24 November 2020

\begin{abstract}
Barnacles are key space-occupiers in rocky shore communities on European coasts. Barnacles of the species Chthamalus stellatus (Poli, 1791) were collected between June 2014 and May 2015 from two sites, two stations per each site with varying degree of exposure to wave action and anthropogenic pressure (trampling), in the Eastern Mediterranean (Pagasitikos Gulf, Central Greece). This study addresses a knowledge gap in population characteristics of C. stellatus populations in the Eastern Mediterranean, assessing population structure and allometric relationships. Patterns of distribution and abundance (density and percentage cover) were studied both temporally (seasonally) and spatially (water level and site). Morphometric characteristics exhibited spatiotemporal variation. Population density was significantly higher at the site with higher wave exposure. The population cover exhibited high levels of similarity among shore levels, both spatially and temporally. Spatial distribution exhibited a clumped pattern of dispersion in autumn, winter, and spring, mainly in the sheltered site. Six dominant age groups were identified, with the dominant cohort in the third-year class. Significant negative allometric relationships were exhibited between all morphometric characteristics. Differences in growth patterns among populations were indicated, with a higher rate of growth at the site of lower wave exposure.
\end{abstract}

Keywords: Pagasitikos Gulf; Eastern Mediterranean; population structure; age composition; intertidal zone

\section{Introduction}

The intertidal cirripede Chthamalus stellatus (Poli, 1791) comprises one of the most abundant and characteristic sessile marine organisms, with a broad geographic distribution in European coastlines, extending from Scotland to the west coast of Africa, including the Mediterranean and Black Seas [1-6]. C. stellatus commonly occurs from the mid-tidal zone, above the brown and red algal belt, to the supra-littoral fringe $[1,7,8]$.

Chthamalus species are stress tolerant, inhabiting a refuge from more competitive, faster growing, and more prolific balanids that cannot tolerate the frequently harsh environmental conditions in the upper shore [9]. C. stellatus often co-occurs with the sympatric species Chthamalus montagui, exhibiting extensive overlap in geographic range, occurring along the northeastern Atlantic coast and in the Mediterranean and Black Seas [2]. The species are separated to an extent by habitat at both regional and local scales, resulting in differences in their vertical and horizontal zonation, with C. stellatus predominantly present in the mid-shore of more wave-exposed shores (2-3 Ballantine scale) [10-14]. 
In several cases, what was considered a single Chthamalus population were in fact distinct sympatric species. Southward [11] clarified the case and showed that C. stellatus comprises two distinct species, C. stellatus and C. montagui. In some cases, mixed populations of these two species of Chthamalus may be found on the same shore, while in other localities only one of the species is present [15]. Although it is not very difficult to distinguish species of the genus Chthamalus based on morphology [11], genetic determination might, sometimes, be more reliable [16].

In the Eastern Mediterranean, C. stellatus also co-occurs with another chthamalid species, Euraphia depressa [17-19], with a more restricted and fragmented vertical distribution in exposed shores, or in cryptic habitats lower on the shore [2]. Distribution of E. depressa in the splash zone usually extends above C. stellatus, with small aggregations in crevices within the supra-littoral fringe [20].

Numerus abiotic factors, mainly water flow [21] and shore height [22], coupled with biotic conditions, such as recruitment rates [23] and aggregation [24,25], have been suggested to affect barnacle growth and morphology. Barnacle distribution and density can be affected by substratum heterogeneity [26-29], competition, predation [30], habitat rugosity [31], thermotolerance [32,33], and local hydrographical regimes [31,34-36].

Although a number of studies have been carried out on the biology, distribution, and ecology of C. stellatus in the Mediterranean Sea [2,6,22,37], little is known of the occurrence and population characteristics of C. stellatus in the Eastern Mediterranean, apart from fragmented information (morphometry, distribution, ecology, reproduction) occasionally collected in the framework of several ecological studies [20,38-40].

The objectives of the present study were to assess the spatial and temporal variation of the biometric characters, cover, abundance, and pattern of distribution of $C$. stellatus among shores with varying degrees of exposure and anthropogenic pressure. The aim was to address a knowledge gap on population characteristics of $C$. stellatus with an extensive assessment of its population structure and characteristics, spatial distribution, and allometric relationships from the mid-tidal zone above the algal belt to the supralittoral fringe in Pagasitikos Gulf (Eastern Mediterranean). This study is part of a broader design aimed at keeping records of changes in coastal communities of the Eastern Mediterranean in order to identify possible future ecological changes and recognize the effects of global warming [41-49].

\section{Materials and Methods}

\subsection{Study Area}

Pagasitikos is a semi-enclosed landlocked gulf located in the northwestern part of the Aegean Sea (Figure 1). The mean depth is $69 \mathrm{~m}$, with its deepest section $(108 \mathrm{~m})$ located in the eastern part, where larger depth gradients are observed. The total gulf area is $520 \mathrm{~km}^{2}$ and total volume $36 \mathrm{~km}^{3}$ [50], and is connected to the Aegean Sea and North Evoikos through the narrow $(5.5 \mathrm{~km})$ and relatively deep (80 m) Trikeri Channel [51]. Pagasitikos is a rather sensitive ecosystem due to its semi-enclosed nature and shallow depths. The predominant weak winds of the area result in small to moderate water currents, while renewal occurs mainly through the deep-water layer of the Trikeri Channel [52]. In contrast with other enclosed gulfs in Greece, Pagasitikos is considerably less eutrophic, with a unique and stable circulation pattern that includes a cyclone in the central-west and an anticyclone in the eastern part [53]. Water renewal of the gulf takes approximately 105 days, according to Petihakis et al. [54]. The only major city is Volos, located in the northern part of the gulf, with a population of 120,000 inhabitants and a well-developed industrial sector. 


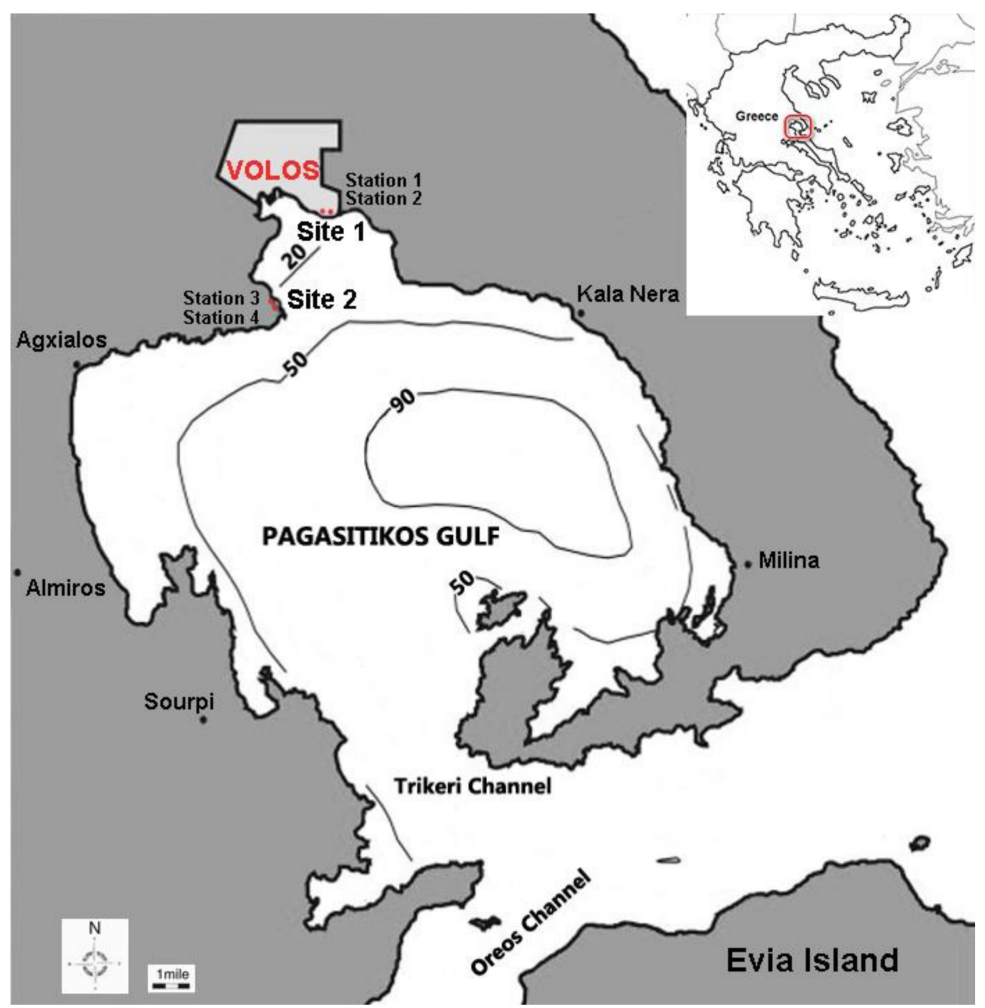

Figure 1. Pagasitikos Gulf depth profile and sample locations, Site 1 (exposed, latitude: 39.347554 and longitude: 22.972509) and Site 2 (sheltered, latitude: 39.297895 and longitude: 22.941898).

\subsection{Field Sampling}

A broad-scale survey of $C$. stellatus density on natural shores was performed in the surrounding area of Volos city (Central Greece) between June 2014 and June 2015. The species were identified using external morphological characteristics according to Southward [11]. Four study stations were selected (Figure 1) based on the degree of exposure and anthropogenic pressure. Two stations were selected at each site in order to obtain disparate samples. Stations one and two were located at the first study site (Site 1: Plakes, latitude: 39.347554 and longitude: 22.972509), which is characterized by mid to high wave exposure, which is about $2-3$ on the Ballantine Scale (approximately $14^{\circ}$ slope) and high anthropogenic pressure (trampling by swimmers) year round. Stations three and four, located at the second study site (Site 2: Agios Stefanos, latitude: 39.297895 and longitude: 22.941898), are characterized by low wave exposure of about $5-6$ on the Ballantine Scale (approximately $9^{\circ}$ slope) and low anthropogenic pressure only in the summer months. Both study sites experience similar wave wash because of maritime traffic. All sampling was carried out in natural barnacle beds.

Sampling was performed in lower-mid midlittoral zone (0.3-0.65 m above Chart Datum) and upper midlittoral zone-lower supralittoral fringe (0.65-1.0 m above Chart Datum) shore levels at all sites. Mean and maximum spring tide amplitudes in the region are $0.25 \mathrm{~m}$ and $0.45 \mathrm{~m}$, respectively. At each shore height in each station, six $10 \times 10 \mathrm{~cm}$ quadrats (metal frame covering a sampling area of $0.01 \mathrm{~m}^{2}$ ) were randomly deployed [55] and digitally photographed using the digital single-lens reflex camera Sony a350 (Sony, Tokyo, Japan). The barnacle cover percentage was estimated and the number of individuals was counted using Image J computer software (Bethesda, MD, USA) [56]. Each sampling station was sampled 1 day/month, within 5 days of either side of the lowest spring tide, between June 2014 and May 2015.

At each sampling site and period, about 80 randomly chosen individuals from both shore levels were scraped from the rock and were transferred to the laboratory. Biometric characteristics, which included basal length (greatest distance between the anterior and posterior), basal width (greatest distance perpendicular to the anterior posterior axis), height (greatest vertical distance from the apex to the shell base), opercular length (greatest distance between the anterior and posterior 
operculum), and opercular width (greatest distance of operculum perpendicular to the anterior posterior axis), were recorded using a digital Vernier caliper to the nearest $0.01 \mathrm{~mm}$ (Figure 2). The wet weight was measured for each individual using the digital analytical balance Ohaus PR64/E (OHAUS, Parsippany, NJ, USA) to the nearest $0.0001 \mathrm{~g}$.

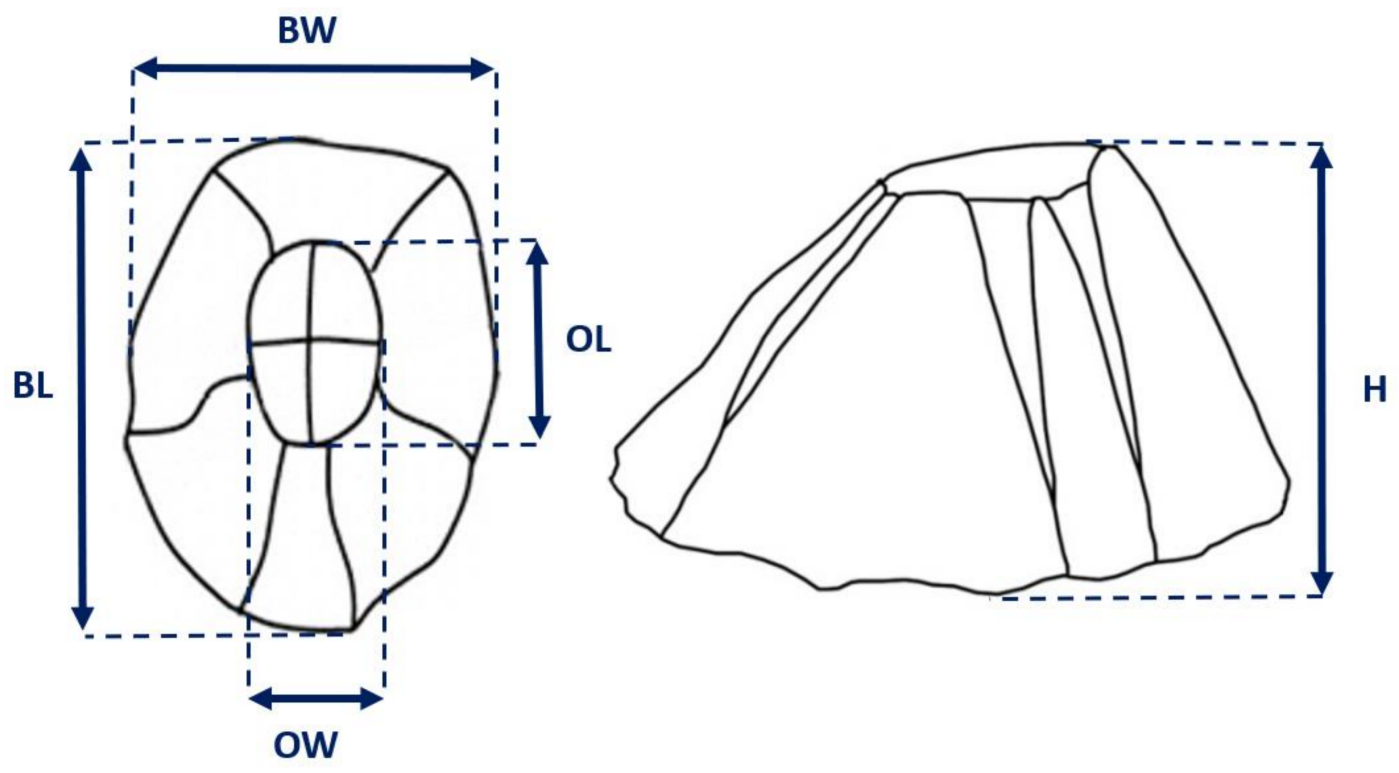

Figure 2. Measured shell dimensions: basal length (BL), basal width (BW), height (H), opercular length (OL), and opercular width (OW).

The main abiotic factors, i.e., temperature, salinity, and dissolved oxygen, were measured on the water surface with the portable instrument HACK HQ 40d multi (HACK, Colorado, CO, USA). The pH was measured with the portable instrument WTW PH 340i/SET (WTW, Weilheim, Germany).

\subsection{Data Analysis}

The null hypothesis of no significant spatial and temporal differences in the abundance and the mean values of the biometric characters of the barnacle were tested with a one-way ANOVA [57] and ANOVA General Linear Model using a least squares regression approach. Tukey's pairwise comparisons were used to identify possible differences between sample means. Normal distribution was assessed using the Anderson-Darling normality test. The Bartlett and Levene tests were used to assess homogeneity of variance. Statistical analyses were performed using Minitab 19 software (Minitab, Pennsylvania, PA, USA) at an alpha level of 0.05.

For all analyses, when variances were found to be heterogenous, transformations were made. In cases when transformations failed to homogenize variances, the analysis proceeded on untransformed data. Analysis of variance is robust to violation of the assumption of homogeneity of variance if the experiment has a large number of observations and is balanced [57].

Non-metric Multi-Dimensional Scaling (nMDS), based on the of Bray-Curtis similarity index using the Unweighted Pair Group Method with Arithmetic mean (UPGMA) [58] was used as a means of visualizing the level of $C$. stellatus cover similarity between sampling sites, seasons, and shore levels. The cover percentage was estimated on a scale of $100 \mathrm{~cm}^{2}$ and was analyzed using cluster analysis based on the Bray-Curtis similarity index [59] with the PRIMER package [60] (PRIMER-e, Auckland, New Zealand). To normalize data and to avoid skewness, a fourth root transformation was applied on the data prior to calculating similarities [61]. 
The spatial distribution of $C$. stellatus was estimated calculating the Morisita index of aggregation (I $\delta$ ) $[62,63]$. To test the null hypothesis of randomness (no deviation from random distribution), (I $\delta=1)$ the chi-square test was used (d.f. $=n-1)[64,65]$. Spatial and temporal abundance variation was assessed using one-way ANOVA.

The equation describing the best fit (highest correlation coefficient) was identified with the use of Curve Expert statistical software (version 1.4) (Hyams Development, Alabama, AL, USA). All dentified relationships were curvilinear power regression equations $\left(Y=a X^{b}\right)$. Allometric relationships were assessed for each population and were compared using the standard student $\mathrm{t}$-test. Regression equations for each population were compared between sampling sites using the two-sample t-test. Length frequency distributions calculated per $0.5 \mathrm{~mm}$ size class were divided into age groups using Bhattacharya's method [66] in order to obtain initial guesses using the software FiSAT II (FAO, Rome, Italy) (version 1.2.2.) [67].

\section{Results}

\subsection{Physico-Chemical Measurements}

The physical parameters measured in the water surface showed similar spatiotemporal values among sampling sites. Temperature ranged seasonally from $13.20^{\circ} \mathrm{C}$ (March 2015) to $27.80^{\circ} \mathrm{C}$ (July 2014). Salinity ranged seasonally from 37.80 psu (January 2015) to $40.05 \mathrm{psu}$ (August 2014). Monthly surface temperature and salinity exhibited minor variations between sites (Table 1).

Table 1. Spatial variation of the physical ( $\mathrm{T}$, temperature; $\mathrm{S}$, salinity) and chemical $\left(\mathrm{pH} ; \mathrm{O}_{2}\right.$, dissolved oxygen) parameters recorded in the Pagasitikos Gulf surface layer.

\begin{tabular}{|c|c|c|c|c|c|c|c|c|}
\hline \multirow{2}{*}{$\begin{array}{l}\text { Sampling } \\
\text { Period }\end{array}$} & \multicolumn{4}{|c|}{ Site 1} & \multicolumn{4}{|c|}{ Site 2} \\
\hline & $\mathrm{T}\left({ }^{\circ} \mathrm{C}\right)$ & $S$ (psu) & $\mathrm{pH}$ & $\mathrm{O}_{2}\left(\mathrm{mg} \mathrm{L}^{-1}\right)$ & $\mathrm{T}\left({ }^{\circ} \mathrm{C}\right)$ & $\mathrm{S}$ (psu) & $\mathrm{pH}$ & $\mathrm{O}_{2}\left(\mathrm{mg} \mathrm{L}^{-1}\right)$ \\
\hline June & 25.27 & 39.00 & 8.24 & 5.71 & 25.81 & 39.40 & 8.26 & 6.61 \\
\hline July & 27.80 & 39.20 & 8.23 & 5.45 & 27.60 & 39.56 & 8.26 & 5.44 \\
\hline August & 27.50 & 40.05 & 8.31 & 5.02 & 27.31 & 39.50 & 8.26 & 5.06 \\
\hline September & 24.10 & 38.84 & 8.29 & 5.92 & 24.43 & 38.53 & 8.29 & 4.92 \\
\hline October & 20.25 & 38.15 & 8.35 & 5.54 & 19.97 & 38.20 & 8.31 & 5.22 \\
\hline November & 17.90 & 38.15 & 8.39 & 4.67 & 17.95 & 38.72 & 8.34 & 4.48 \\
\hline December & 15.95 & 37.90 & 8.24 & 4.97 & 15.93 & 38.11 & 8.31 & 5.99 \\
\hline January & 13.52 & 37.80 & 8.33 & 4.01 & 13.80 & 38.10 & 8.27 & 5.21 \\
\hline February & 13.45 & 38.15 & 8.27 & 5.11 & 13.46 & 38.33 & 8.28 & 5.04 \\
\hline March & 13.20 & 38.40 & 8.29 & 6.49 & 13.53 & 38.81 & 8.23 & 4.76 \\
\hline April & 16.30 & 38.91 & 8.28 & 6.49 & 15.91 & 38.80 & 8.28 & 6.62 \\
\hline May & 22.70 & 38.82 & 8.26 & 5.48 & 22.50 & 38.87 & 8.29 & 5.88 \\
\hline
\end{tabular}

\subsection{Biometric Relationships}

The total number of $C$. stellatus specimens collected was 2511 . Basal length ranged from 1.75 to $14.3 \mathrm{~mm}$, basal width from 0.52 to $14.00 \mathrm{~mm}$, height from 0.04 to $6.01 \mathrm{~mm}$, opercular length from 0.61 to $5.61 \mathrm{~mm}$, opercular width from 0.25 to $4.90 \mathrm{~mm}$, and weight from 0.0009 to $0.7540 \mathrm{~g}$. No biometric spatiotemporal differences were recorded among sampling stations within each sampling site and data were pooled together. Significant temporal variation of biometric characters was exhibited, with the highest values in winter and lowest values in spring. Significant spatial differences were exhibited in all biometric relationships, with significantly higher values indicated for the C. stellatus population located in the sheltered site (Site 2).

The full set of biometric measurements at each sampling site is presented in Table 2. Barnacle basal length, basal width, height, opercular length, and weight frequency distributions (Figures 3-8) indicated greater variability of the morphometric characteristics of the $C$. stellatus population at the sheltered site (Site 2). 
Table 2. Spatial and temporal variation of the biometric characters, number (n), basal length (BL), basal width (BW), height $(\mathrm{H})$, opercular length $(\mathrm{OL})$, opercular width $(\mathrm{OW})$, weight $(\mathrm{Wt})$, represented as mean value \pm standard error (SE), one-way ANOVA results $(F, P)$ and Tukey's pairwise comparisons, of C. stellatus populations in Pagasitikos Gulf.

\begin{tabular}{cccccccc}
\hline $\begin{array}{c}\text { Sampling } \\
\text { Period }\end{array}$ & $\begin{array}{c}\text { No. of } \\
\text { Individuals }\end{array}$ & $\mathbf{B L} \pm \mathbf{S E}$ & $\mathbf{B W} \pm \mathbf{S E}$ & $\mathbf{H} \pm \mathbf{S E}$ & $\mathbf{O L} \pm \mathbf{S E}$ & $\mathbf{O W} \pm \mathbf{S E}$ & $\mathbf{W t} \pm \mathbf{S E}$ \\
\hline Site & $(\mathrm{n})$ & & & & & & \\
Site 1 & 1199 & $6.85 \pm 0.05$ & $6.26 \pm 0.05$ & $2.75 \pm 0.02$ & $2.65 \pm 0.02$ & $2.23 \pm 0.01$ & $0.09 \pm 0.002$ \\
Site 2 & 1312 & $7.71 \pm 0.06$ & $7.25 \pm 0.06$ & $2.94 \pm 0.02$ & $2.93 \pm 0.02$ & $2.44 \pm 0.02$ & $0.13 \pm 0.002$ \\
& & $\mathrm{~F}=116.65$, & $\mathrm{F}=146.88$, & $\mathrm{F}=35.17$, & $\mathrm{F}=105.98$, & $\mathrm{F}=76.00$, & $\mathrm{F}=132.13$, \\
& & $p<0.001$ & $p<0.001$ & $p<0.001$ & $p<0.001$ & $p<0.001$ & $p<0.001$ \\
Season & $(\mathrm{n})$ & & & & & \\
Summer & 709 & $7.32^{\mathrm{a}, \mathrm{b}} \pm 0.07$ & $6.75^{\mathrm{b}} \pm 0.07$ & $2.76^{\mathrm{b}} \pm 0.03$ & $2.82^{\mathrm{a}} \pm 0.03$ & $2.36^{\mathrm{a}} \pm 0.02$ & $0.12^{\mathrm{a}} \pm 0.003$ \\
Autumn & 539 & $7.22^{\mathrm{b}, \mathrm{c}} \pm 0.08$ & $6.71^{\mathrm{b}} \pm 0.08$ & $2.88^{\mathrm{a}, \mathrm{b}} \pm 0.03$ & $2.76^{\mathrm{a}, \mathrm{b}} \pm 0.03$ & $2.33^{\mathrm{a}, \mathrm{b}} \pm 0.02$ & $0.11^{\mathrm{b}, \mathrm{c}} \pm 0.003$ \\
Winter & 750 & $7.53^{\mathrm{a}} \pm 0.08$ & $7.06^{\mathrm{a}} \pm 0.08$ & $2.97^{\mathrm{a}} \pm 0.03$ & $2.86^{\mathrm{a}} \pm 0.03$ & $2.39^{\mathrm{a}} \pm 0.02$ & $0.12^{\mathrm{a}, \mathrm{b}} \pm 0.003$ \\
Spring & 513 & $6.99^{\mathrm{c}} \pm 0.09$ & $6.47^{\mathrm{b}} \pm 0.09$ & $2.76^{\mathrm{b}} \pm 0.03$ & $2.69^{\mathrm{b}} \pm 0.03$ & $2.24^{\mathrm{b}} \pm 0.03$ & $0.09^{\mathrm{c}} \pm 0.004$ \\
& & $\mathrm{~F}=7.60$, & $\mathrm{F}=8.39$, & $\mathrm{F}=10.64$, & $\mathrm{F}=6.17$, & $\mathrm{F}=6.67$, & $\mathrm{F}=10.11$, \\
Total & 2511 & $7.29 \pm 2.04$ & $6.78 \pm 2.12$ & $2.85 \pm 0.86$ & $2.79 \pm 0.69$ & $2.34 \pm 0.01$ & $0.11 \pm 0.09$ \\
\hline
\end{tabular}

a,b,c: Results of Tukey's pairwise comparisons. Means that do not share a superscript letter are significantly different.

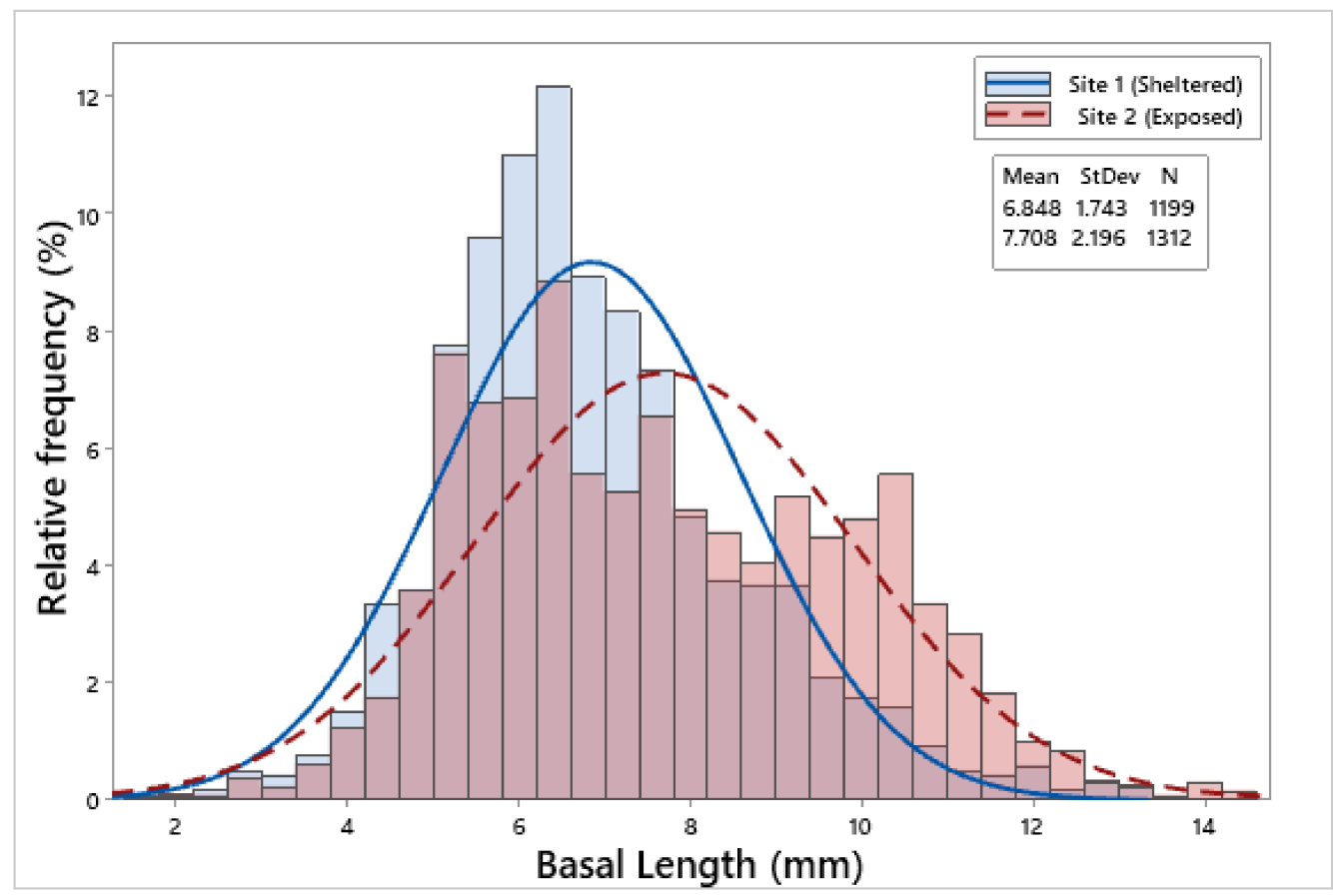

Figure 3. Basal length-frequency distribution of C. stellatus populations with overlaid fitted normal distribution at both sampling sites. 


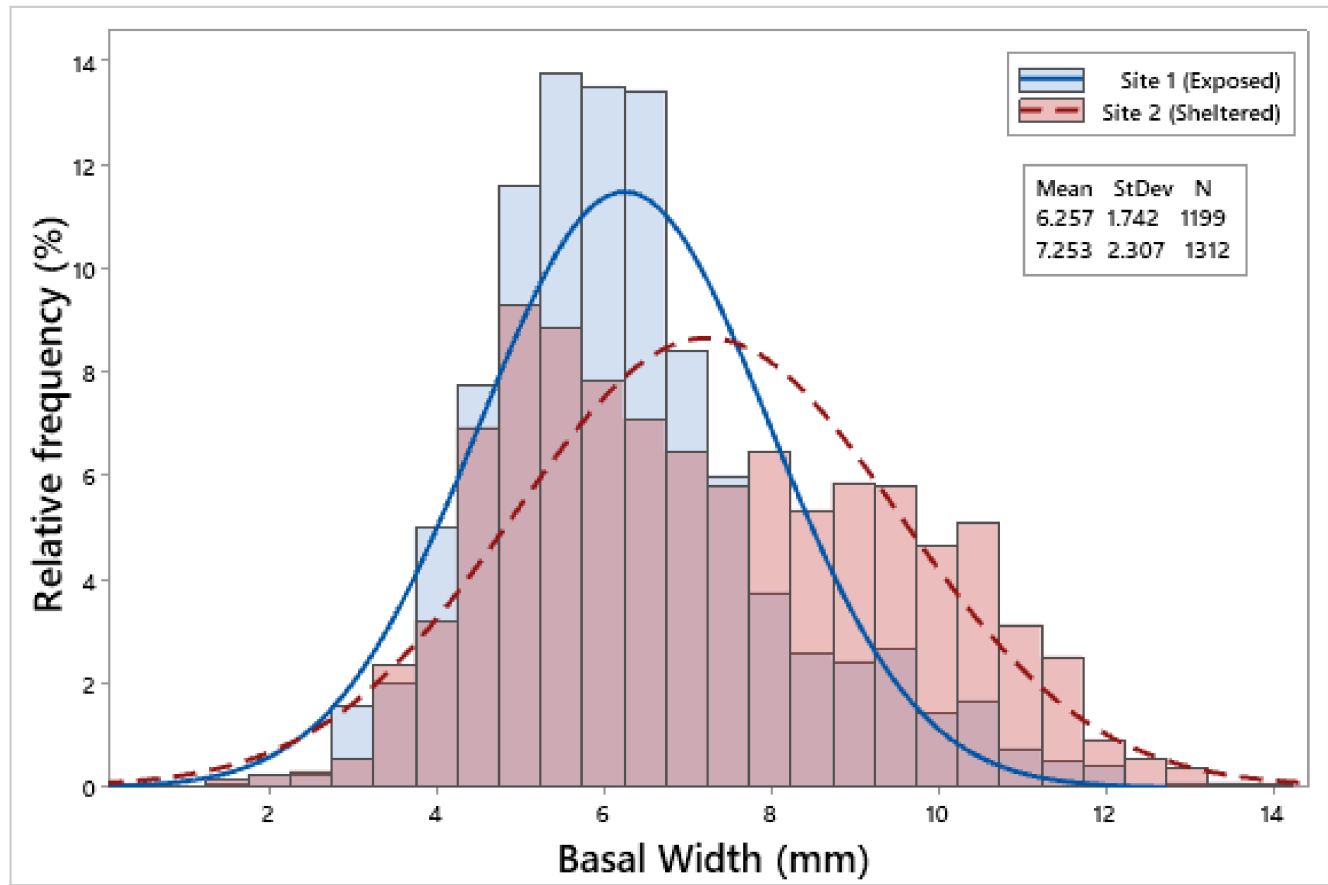

Figure 4. Basal width-frequency distribution of C. stellatus populations with overlaid fitted normal distribution at both sampling sites.

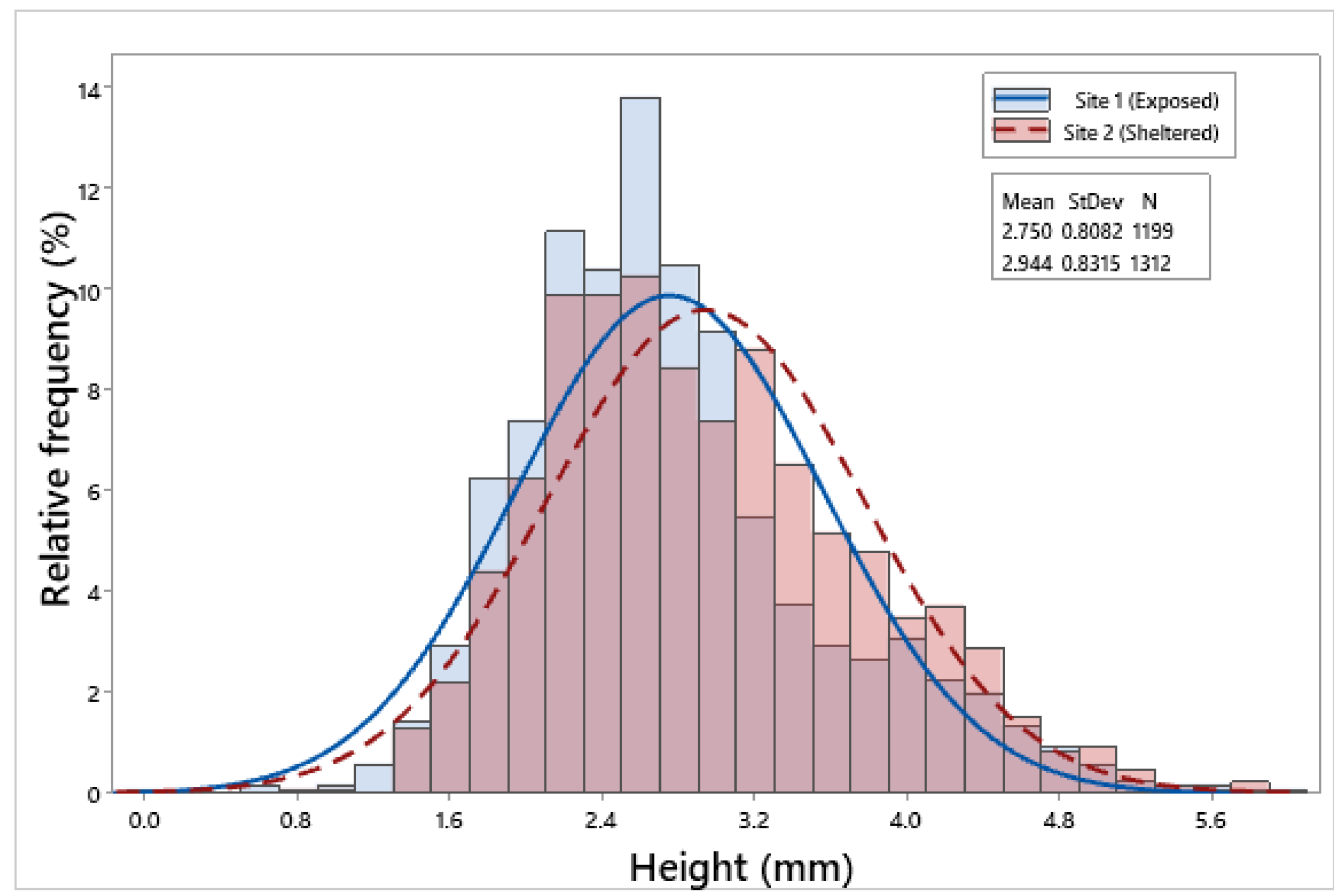

Figure 5. Total shell height-frequency distribution of C. stellatus populations with overlaid fitted normal distribution at both sampling sites. 


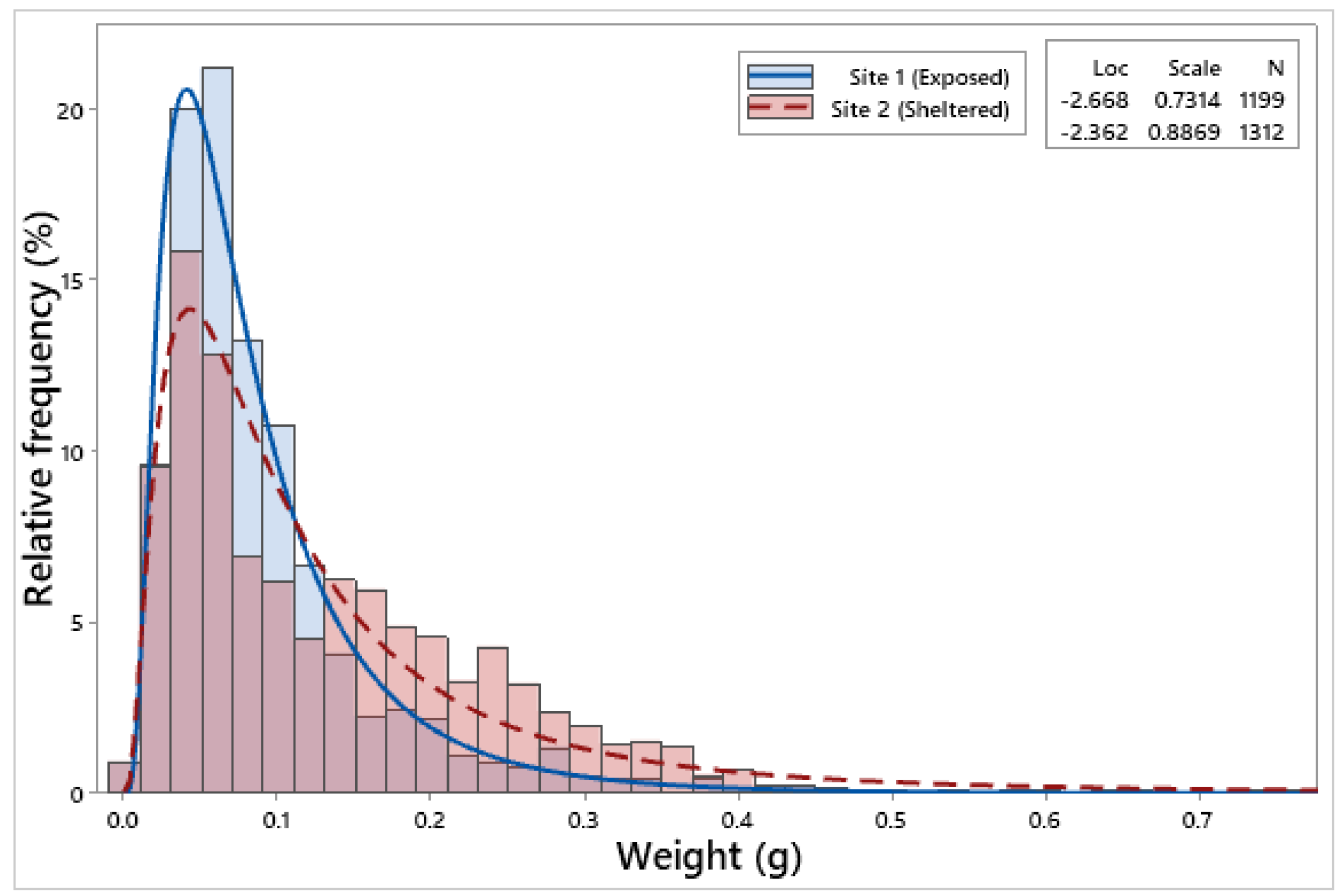

Figure 6. Total weight-frequency distribution of C. stellatus populations with overlaid fitted lognormal distribution at both sampling sites.

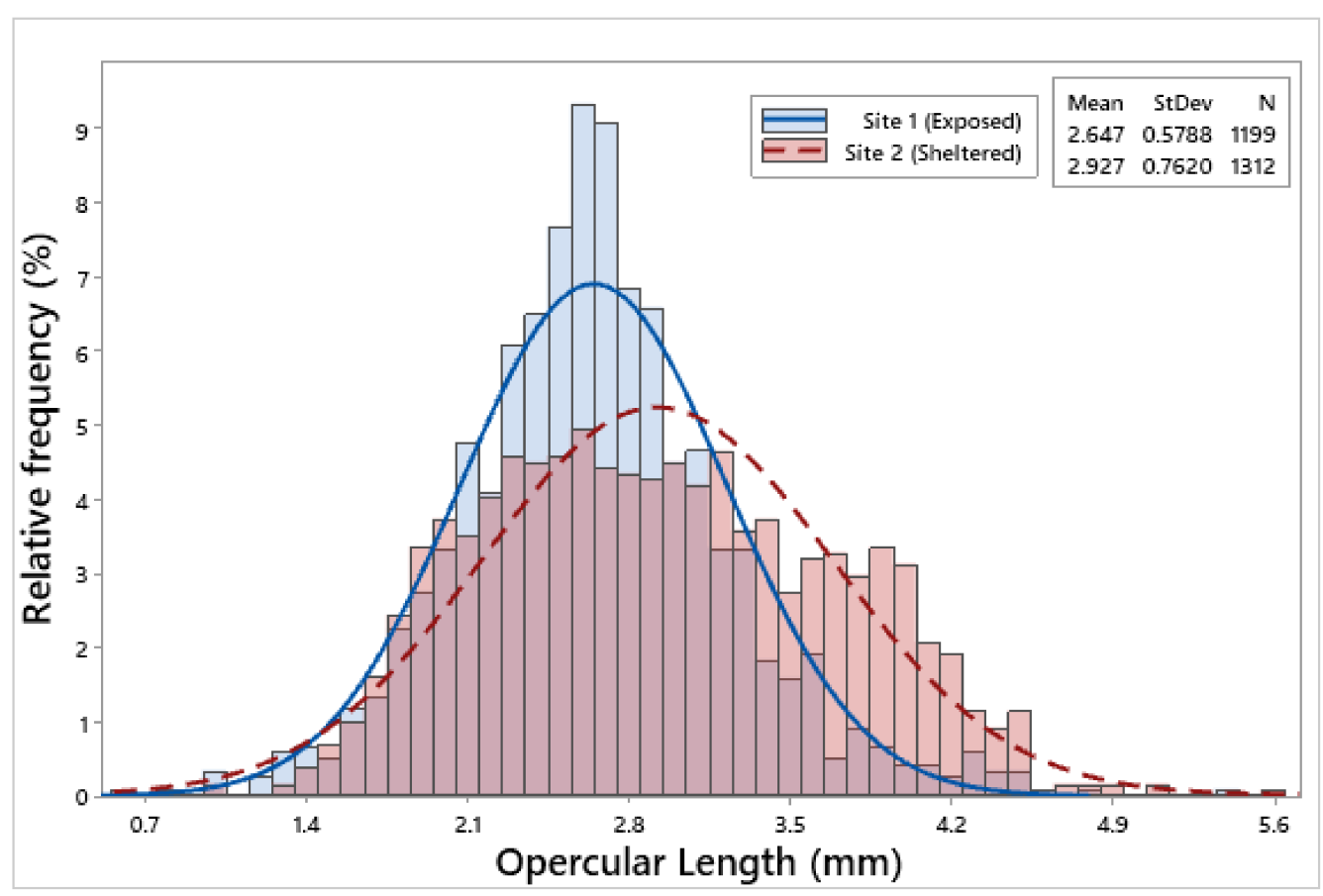

Figure 7. Total opercular length-frequency distribution of $C$. stellatus populations with overlaid fitted normal distribution at both sampling sites. 


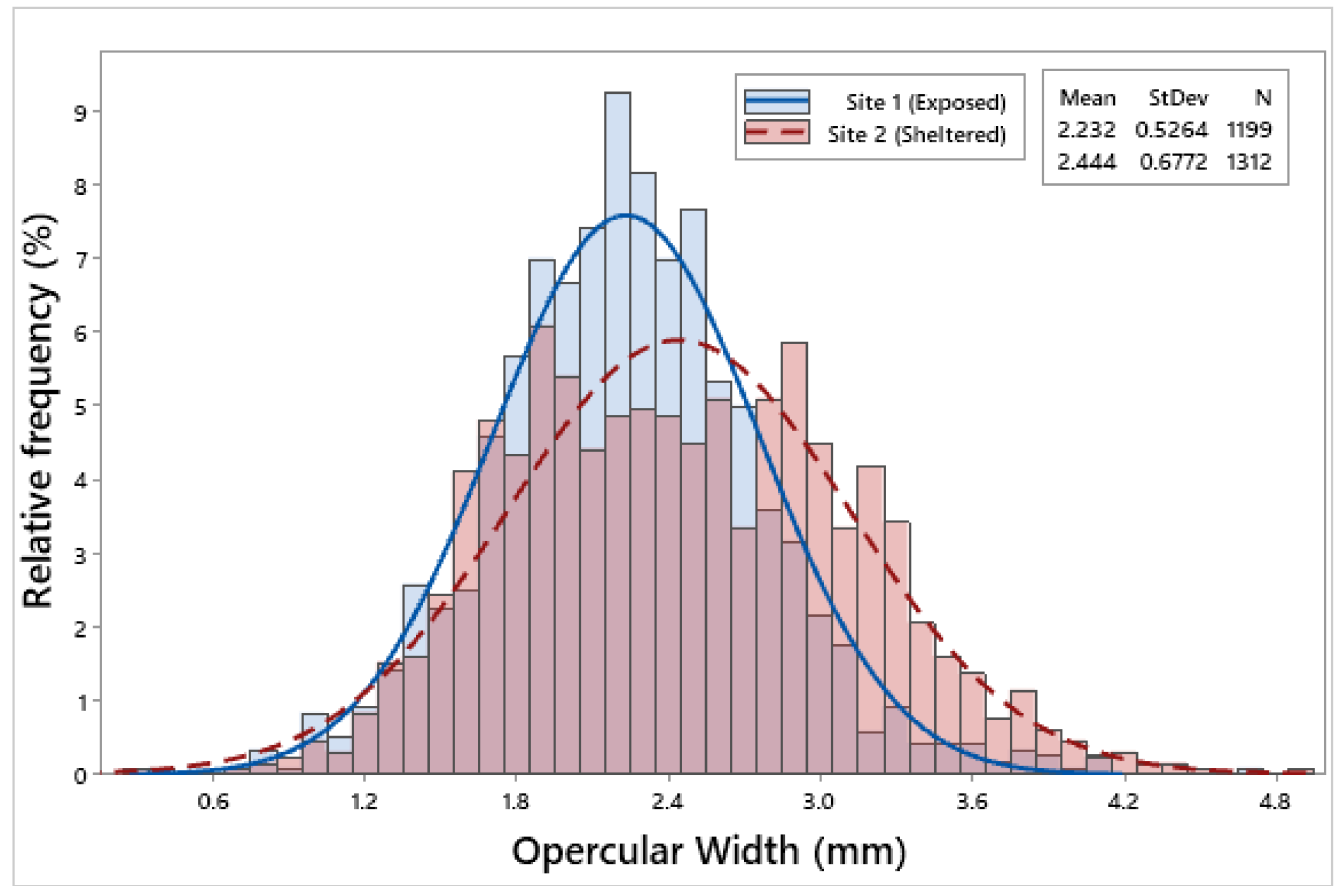

Figure 8. Total opercular width-frequency distribution of C. stellatus populations with overlaid fitted normal distribution at both sampling sites.

\subsection{Allometric Relationships}

Equations describing the best fit (highest correlation coefficient) between different morphometric characteristics of $C$. stellatus populations throughout the sampling period and their allometric relationships are displayed in Table 3.

Table 3. Allometric equations between basal length (BL), basal width (BW), height (H), total weight $(\mathrm{Wt})$, opercular length $(\mathrm{OL})$, and opercular width $(\mathrm{OW})$ of $C$. stellatus populations for sampling sites, Site 1 (exposed) and Site 2 (sheltered), during the study. N: number of individuals, $\mathrm{R}^{2}$ : coefficient of determination, t-test: statistical significance of the allometric relationship, allometry: allometric relationship between the two variables, slopes (b): statistical comparison between the slopes of the equations, intercepts (a): statistical comparison between the intercepts of the equations, significance level (ns: non-significant, ${ }^{*}: p<0.05,{ }^{* *}: p<0.001$ ).

\begin{tabular}{|c|c|c|c|c|c|c|c|}
\hline \multicolumn{6}{|c|}{ Morphometric Relationships } & \multicolumn{2}{|c|}{ Equation Comparison } \\
\hline $\begin{array}{l}\text { Sampling } \\
\text { Site }\end{array}$ & Equation & $\mathbf{N}$ & $\mathbf{R}^{2}$ & t-test & Allometry & Slopes & Intercepts \\
\hline Site 1 & $\mathrm{Wt}=0.000631904 \times \mathrm{BL}^{2.50621}$ & 1199 & 86.5 & $* *$ & Negative & \multirow{2}{*}{ ** } & \multirow{2}{*}{ ** } \\
\hline Site 2 & $\mathrm{Wt}=0.00119825 \times \mathrm{BL}^{2.25133}$ & 1312 & 86.7 & $* *$ & Negative & & \\
\hline Site 1 & $\mathrm{Wt}=0.00118524 \times \mathrm{BW}^{2.29087}$ & 1199 & 86.6 & $* *$ & Negative & \multirow[b]{2}{*}{ * } & \multirow{2}{*}{ * } \\
\hline Site 2 & $\mathrm{Wt}=0.00164777 \times \mathrm{BW}^{2.15174}$ & 1312 & 88.7 & $* *$ & Negative & & \\
\hline Site 1 & $\mathrm{Wt}=0.0104422 \times \mathrm{H}^{2.0243}$ & 1199 & 78.5 & $* *$ & Negative & \multirow{2}{*}{ ns } & \multirow{2}{*}{$* *$} \\
\hline Site 2 & $\mathrm{Wt}=0.0159692 \times \mathrm{H}^{1.89858}$ & 1312 & 76.0 & $* *$ & Negative & & \\
\hline Site 1 & $\mathrm{BL}=3.79544 \times \mathrm{H}^{0.59309}$ & 1199 & 67.7 & $* *$ & Negative & \multirow{2}{*}{$* *$} & \multirow{2}{*}{ ns } \\
\hline Site 2 & $\mathrm{BL}=3.58751 \times \mathrm{H}^{0.71623}$ & 1312 & 72.5 & $* *$ & Negative & & \\
\hline Site 1 & $\mathrm{BL}=1.71255 \times \mathrm{BW}^{0.75949}$ & 1199 & 82.6 & $* *$ & Negative & \multirow[b]{2}{*}{ ns } & \multirow[b]{2}{*}{ ns } \\
\hline Site 2 & $\mathrm{BL}=1.69340 \times \mathrm{BW}^{0.76932}$ & 1312 & 86.6 & $* *$ & Negative & & \\
\hline Site 1 & $\mathrm{BW}=3.47928 \times \mathrm{H}^{0.58979}$ & 1199 & 61.4 & $* *$ & Negative & \multirow{2}{*}{ ** } & \multirow{2}{*}{ * } \\
\hline Site 2 & $\mathrm{BW}=3.15446 \times \mathrm{H}^{0.77814}$ & 1312 & 70.7 & $* *$ & Negative & & \\
\hline Site 1 & $\mathrm{OL}=1.35775 \times \mathrm{OW}^{0.83600}$ & 1199 & 90.1 & ** & Negative & \multirow{2}{*}{ ns } & \multirow[b]{2}{*}{ ns } \\
\hline Site 2 & $\mathrm{OL}=1.35591 \times \mathrm{OW}^{0.86603}$ & 1312 & 92.8 & $* *$ & Negative & & \\
\hline
\end{tabular}


All morphometric relationships calculated indicated significant negative allometric relationships among variables. Comparison of the regression lines (Table 3) indicated no significant difference in regression lines of basal length vs. basal width, opercular length vs. opercular width, and weight vs. height among sampling sites. Significant differences among sampling sites were observed in the slopes and intercepts of the regression lines of weight vs. basal length, weight vs. basal width, basal length vs. height, and basal width vs. height. Significant differences exhibited between regression lines are indicative of differences in the growth patterns among studied populations.

\subsection{Population Density}

Population density (mean \pm standard deviation) at the exposed site (Site 1) was higher on average in summer (12,762 ind $\left.\mathrm{m}^{-2} \pm 2252\right)$ followed by spring (9664 ind $\left.\mathrm{m}^{-2} \pm 1240\right)$, autumn (9512 ind $\left.\mathrm{m}^{-2} \pm 1862\right)$, and winter (7077 ind $\left.\mathrm{m}^{-2} \pm 1372\right)$. Population density at the sheltered site (Site 2) was higher on average in spring (7351 ind $\mathrm{m}^{-2} \pm 1544$ ) followed by autumn (5832 ind $\left.\mathrm{m}^{-2} \pm 870\right)$, summer (5565 ind $\mathrm{m}^{-2} \pm 978$ ), and winter (5181 ind $\mathrm{m}^{-2} \pm 948$ ). The highest temporal abundance of the total population was recorded in summer (9163 ind $\mathrm{m}^{-2} \pm 1416$ ), followed by spring (8508 ind $\left.\mathrm{m}^{-2} \pm 998\right)$, autumn (7672 ind $\mathrm{m}^{-2} \pm 1096$ ), and winter (6129 ind $\mathrm{m}^{-2} \pm 839$ ). The overall C. stellatus population density was 7868 ind $\mathrm{m}^{-2} \pm 557$. Population density was higher at the exposed site (Site 1; 9754 ind $\mathrm{m}^{-2} \pm 887$ ) compared with the sheltered site (Site 2; 5982 ind $\mathrm{m}^{-2} \pm 563$ ). No population density spatiotemporal differences were recorded among sampling stations within each sampling site and data were pooled together. The ANOVA General Linear Model indicated spatial differences in the population density between sites (exposed-sheltered), with significantly higher abundance observed at the exposed site (Table 4).

Table 4. ANOVA General Linear model results of spatial and temporal effects, degrees of freedom (DF), sum of squares (SS), mean squares (MS), on the surveyed C. stellatus population abundance.

\begin{tabular}{cccccc}
\hline Source of Variation & DF & SS & MS & F & $p$ \\
\hline Site & 1 & 34,143 & 34,143 & 31.09 & $<0.001$ \\
(Exposed-Sheltered) & 1 & 146,494 & 146,494 & 133.39 & $<0.001$ \\
Level (Mid-Upper) & 1 & 1478 & 1478 & 1.35 & 0.249 \\
Season & 1 & 101,039 & 1098 & & \\
Error & 92 & & & \\
Total & 95 & 283,154 & & &
\end{tabular}

Population density at the mid-shore level (lower-mid midlittoral zone) was higher (11,774 ind $\left.\mathrm{m}^{-2} \pm 717\right)$ compared with the upper shore level (upper midlittoral zone-lower supralittoral fringe; $3962 \mathrm{ind}^{-2} \pm 302$ ). The ANOVA General Linear Model results (Table 4) indicated spatial differences in the population density between shore levels (mid midlittoral zone-upper midlittoral zone) with significantly higher abundance observed at the mid midlittoral zone. Temporal differences in the density of the total population were also indicated (Table 4), but not statistically significant.

The influence that each factor (location, shore level, and season) exerts on the mean population density of the C. stellatus population is shown in Figure 9. 


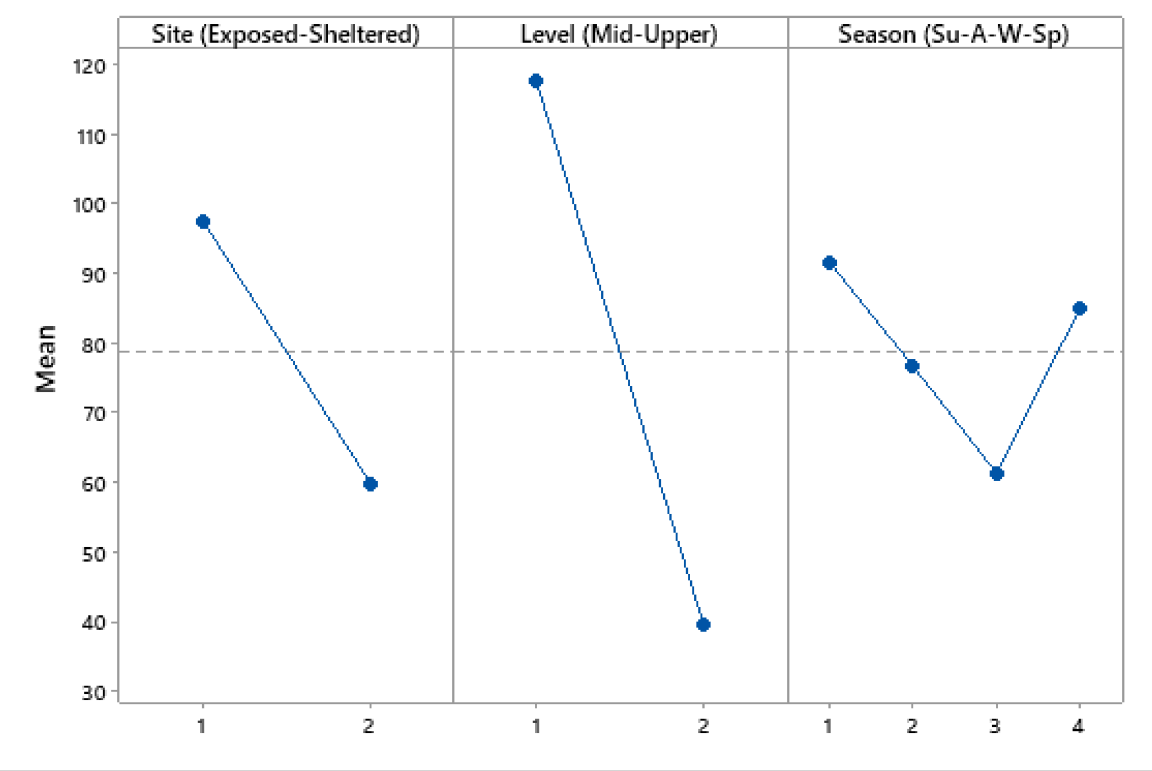

Figure 9. Main effects plot of the influence of each factor (sampling site, shore level, and season) on the mean C. stellatus population density.

The extent of the temporal and spatial similarity of $C$. Chthamalus population cover is shown in Figure 10. The nonmetric multidimensional scaling (nMDS) plot indicated a high level of similarity ( $81 \%$ similarity) in the cover percentage of $C$. stellatus between levels. A low similarity level was indicated between exposure level and sampling season.

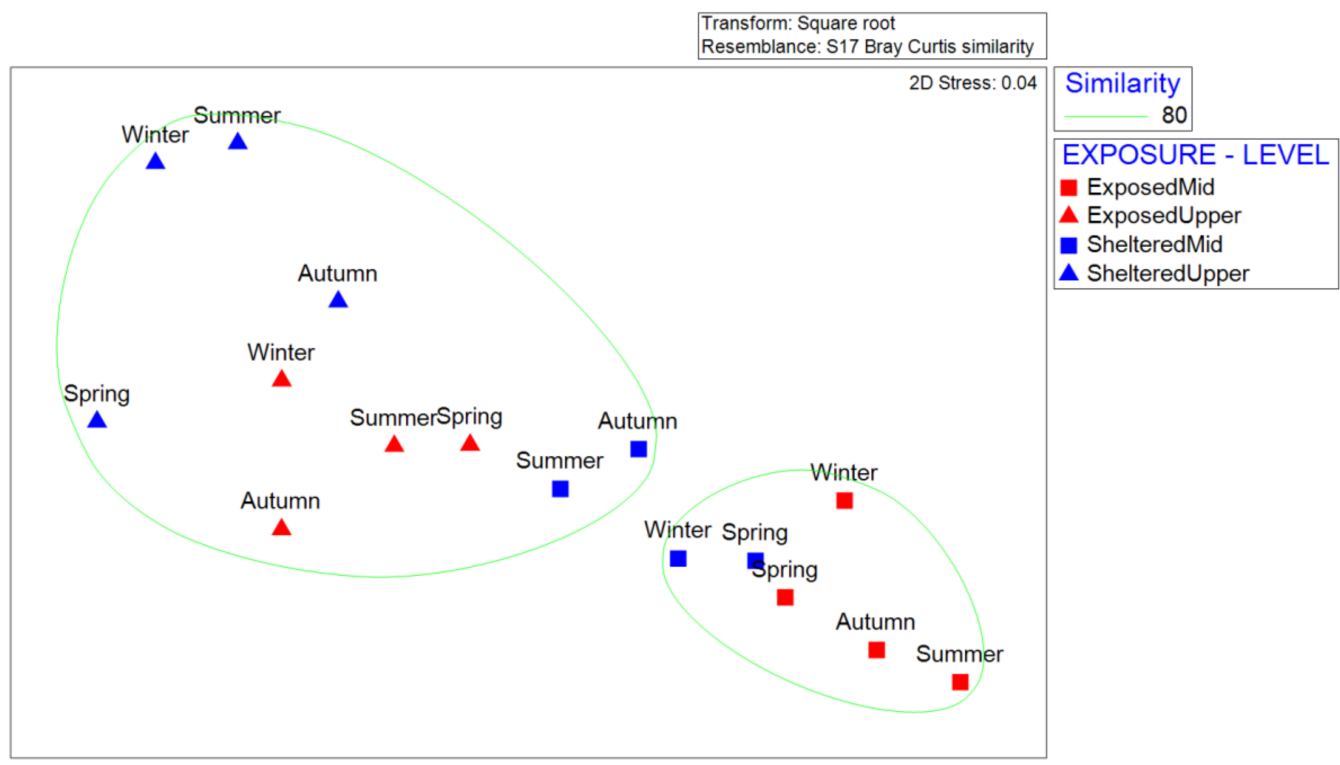

Figure 10. Multidimensional scaling ordination plot of the level of similarity of C. stellatus population cover among sampling sites, shore levels, and seasons, based on the Bray-Curtis similarity index of square root-transformed cover percentages. Closer points indicate higher similarity. The ellipses group mid and upper shore and have no statistical relevance.

Cluster analysis of C. stellatus population cover is shown in Figure 11. Cluster analysis of C. stellatus cover percentage indicated two major groups with a high level of similarity: the upper shore-level group with $81 \%$ similarity (group A) and the lower shore level group with $88 \%$ similarity (group B). 


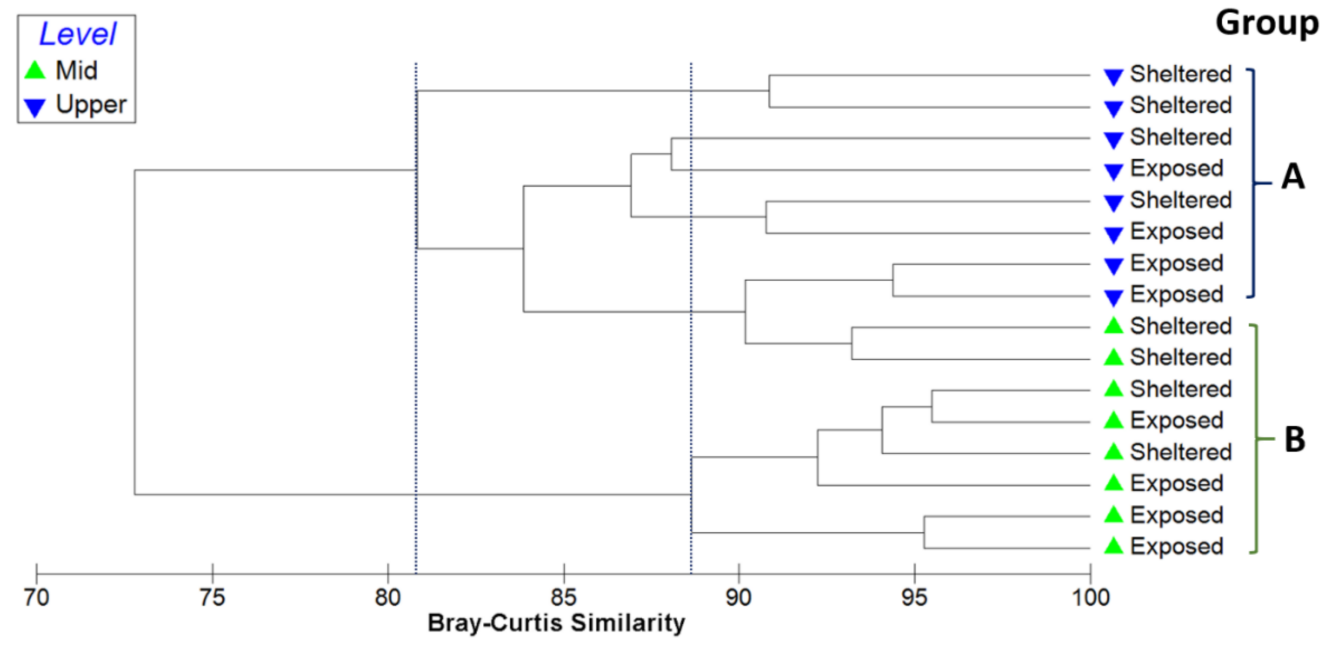

Figure 11. Dendrogram for hierarchical clustering of $C$. stellatus population cover at the study sites and shore levels using group-average clustering of Bray-Curtis similarities based on square root-transformed cover percentages.

\subsection{Distribution Pattern}

Spatial point pattern analysis was used to examine the spatial distribution of C. stellatus. A significant clustered spatial dispersion pattern was exhibited in the upper shore level of the sheltered site (Site 2) during autumn and spring. A significant clustered spatial dispersion pattern was exhibited in the upper shore level of the exposed site (Site 1) and mid-shore level of the sheltered site in winter (Table 5).

Table 5. Population density (ind $\mathrm{m}^{-2}$ ) and dispersion pattern of C. stellatus populations per sampling site, level, and period, (standard deviation (SD), Morisita index of aggregation (I $\delta$ ), degrees of freedom (DF), chi-square values corresponding to the statistic obtained with an indication of their significance at $95 \%$ confidence level $\left(X^{2}\right)$, ns (no significance)).

\begin{tabular}{|c|c|c|c|c|c|c|c|c|}
\hline $\begin{array}{l}\text { Sampling } \\
\text { Season }\end{array}$ & Sites & $\begin{array}{l}\text { Shore } \\
\text { Level }\end{array}$ & $\begin{array}{c}\text { Population } \\
\text { Density } \\
\left.\text { (ind } / \mathrm{m}^{2} \pm \mathrm{SD}\right)\end{array}$ & I $\delta$ & $\mathrm{X} 2$ & $\begin{array}{c}\text { Dispersion } \\
\text { Pattern }\end{array}$ & $\begin{array}{l}\text { Significance } \\
\text { Level }\end{array}$ & DF \\
\hline \multirow[t]{2}{*}{ Summer } & Site 1 & Mid & $19.950 \pm 2.907$ & 1.01 & 11.73 & random & $<0.05$ & 5 \\
\hline & Site 1 & Upper & $5.574 \pm 1.184$ & 1.04 & 11.03 & random & ns & 5 \\
\hline \multirow[t]{2}{*}{ Summer } & Site 2 & Mid & $7.841 \pm 2.823$ & 1.05 & 28.78 & random & $<0.001$ & 5 \\
\hline & Site 2 & Upper & $3.289 \pm 2.199$ & 1.06 & 11.32 & random & $<0.05$ & 5 \\
\hline \multirow[t]{2}{*}{ Autumn } & Site 1 & Mid & $14.947 \pm 4,245$ & 1.01 & 4.87 & random & ns & 5 \\
\hline & Site 1 & Upper & $4.078 \pm 1.623$ & 1.01 & 3.05 & random & ns & 5 \\
\hline \multirow[t]{2}{*}{ Autumn } & Site 2 & Mid & $7.696 \pm 3.220$ & 1.02 & 11.39 & random & $<0.05$ & 5 \\
\hline & Site 2 & Upper & $3.967 \pm 2.012$ & 1.09 & 16.99 & clustered & $<0.001$ & 5 \\
\hline \multirow[t]{2}{*}{ Winter } & Site 1 & Mid & $10.969 \pm 3.590$ & 1.00 & 0.83 & random & ns & 5 \\
\hline & Site 1 & Upper & $3.186 \pm 686$ & 1.07 & 19.86 & clustered & $<0.001$ & 5 \\
\hline \multirow[t]{2}{*}{ Winter } & Site 2 & Mid & $8.054 \pm 1.352$ & 1.15 & 55.17 & clustered & $<0.001$ & 5 \\
\hline & Site 2 & Upper & $2.308 \pm 1.452$ & 1.02 & 2.23 & random & ns & 5 \\
\hline \multirow[t]{2}{*}{ Spring } & Site 1 & Mid & $12.849 \pm 2.964$ & 1.01 & 11.76 & random & $<0.05$ & 5 \\
\hline & Site 1 & Upper & $6.479 \pm 2.737$ & 1.02 & 4.90 & random & ns & 5 \\
\hline \multirow[t]{2}{*}{ Spring } & Site 2 & Mid & $11.889 \pm 3.473$ & 1.00 & 2.95 & random & ns & 5 \\
\hline & Site 2 & Upper & $2.813 \pm 1.193$ & 1.09 & 19.44 & clustered & $<0.001$ & 5 \\
\hline
\end{tabular}

\subsection{Age Composition}

Six dominant age groups were identified (Figure 12, Table 6). The dominant cohort was the third-year class, with $45 \%$ of the total population. 


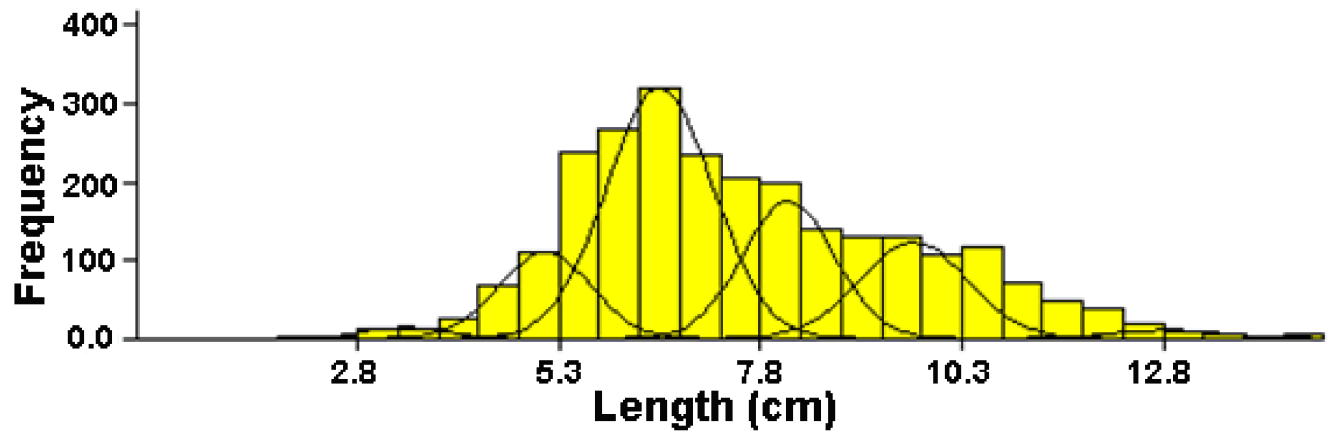

Figure 12. C. stellatus population cohorts identified with Bhattacharya's method.

Table 6. Population characteristics of the age groups identified for the entire $C$. stellatus population (mean length, standard deviation, population size, separation index, and population percentage at each age class).

\begin{tabular}{cccccc}
\hline Age Group & $\begin{array}{c}\text { Mean Length } \\
(\mathbf{m m})\end{array}$ & $\begin{array}{c}\text { Standard } \\
\text { Deviation }\end{array}$ & $\begin{array}{c}\text { Population } \\
\text { Size }\end{array}$ & $\begin{array}{c}\text { Separation } \\
\text { Index (SI) }\end{array}$ & $\begin{array}{c}\text { Population } \\
\%\end{array}$ \\
\hline 1 & 3.32 & 0.47 & 33 & & 1.40 \\
2 & 5.07 & 0.57 & 314 & 2.37 & 13.34 \\
3 & 6.50 & 0.66 & 1059 & 2.07 & 45.01 \\
4 & 8.10 & 0.57 & 500 & 2.10 & 21.25 \\
5 & 9.65 & 0.67 & 413 & 2.07 & 17.55 \\
6 & 12.82 & 0.65 & 34 & 2.36 & 1.44 \\
\hline
\end{tabular}

\section{Discussion}

Barnacles are key space-occupiers in rocky shore communities on European coasts [68] that interact with other species and, hence, affect overall biodiversity [69,70]. The barnacle $C$. stellatus is one of the most common and characteristic sessile invertebrates in midlittoral rocky shore assemblages of the Northwest Mediterranean [22,71]. It occurs at various heights on the shore and is most abundant in the midlittoral shore, exhibiting considerable variation in density among sites $[4,72]$. This study assessed population characteristics of $C$. stellatus located from the mid-tidal zone above the algal belt to the supralittoral fringe in Pagasitikos Gulf (Eastern Mediterranean).

Distribution of $C$. stellatus in the present study extended to the supralittoral fringe, similarly to other locations, such as the Gulf of Genoa (Ligurian Sea) [4] and the Istrian peninsula coast (Adriatic) [6], in contrast to the Gulf of Trieste (Adriatic) [4,73] and Habonim (Israel) [20] where C. stellatus distribution was confined strictly to the midlittoral zone.

Results indicated that distribution of $C$ stellatus in the study area conform to the common model of zonation suggested by Connell [35], where lower distribution limits are determined by biotic factors (competition and predation), while upper limits are set by physical factors. On the contrary, Guy-Haim et al. [20], suggested that the Competition Model cannot be adapted to Mediterranean intertidal zonation for C. stellatus and that other models, dominated by physical enforcement and pre-settlement recruitment-limiting factors, may prevail in this ecosystem.

\subsection{Biometric Relationships}

Significant differences were exhibited on a temporal scale for all biometric relationships of C. stellatus population, with highest values in winter and lowest values in spring, possibly attributed to local patterns of reproduction and recruitment. C. stellatus shows distinct seasonal patterns in reproduction, with a peak in breeding in south-western Ireland during the summer [19]. Benedetti-Cecchi et al. [22] emphasized the importance of both regional and local processes in regulating patterns of recruitment, growth and mortality of $C$. stellatus in the Northwest Mediterranean. 
All biometric relationships exhibited significant differences on a spatial scale, with significant higher values recorded for the population located in the sheltered site, indicating greater variability of the morphometric characteristics of $C$. stellatus population compared to the exposed site. Those differences could be attributed to the variable degree of wave exposure, slope and anthropogenic pressure among sites and density differences, affecting larval recruitment, thus impacting population community structure $[31,74,75]$.

Factors determining barnacle size include responses to abiotic conditions such as shore height [22] and to biotic conditions such as recruitment rates [76]. In our case, shore height was similar among habitats. It could therefore be suggested that differences in animal size may be attributed to variations in prevailing hydrodynamic conditions between the two sites and/or recruitment rates. Many studies have indicated that barnacles exhibit a faster growth rate in areas of higher flow, presumably because of the increased delivery of suspended particles [77-81]. Barnacles on wave exposed shores may experience longer submergence times and hence greater opportunities for feeding and reduced thermal stress [21]. Aggregation has, also, been suggested to affect barnacle shape, resulting in elongated individuals $[24,25]$ and biometric relationships between sites.

The observed differences in barnacle size between sites may have wider biological and ecological effects, since size is directly related to several metabolic functions (e.g., reproductive output, ingestion rate, oxygen consumption) [82-84]. In the case of barnacles, animal size has been correlated with larval production [85] and affects vulnerability to whelk predation [86] or limpet bulldozing [87]. As such, any factors affecting the size of barnacles will likely influence population dynamics and the degree of interaction with other species.

\subsection{Allometric Relationships}

Significant negative allometric relationships exhibited within the morphometric characteristics of the populations, indicated differences in growth patterns, with the tendency of $C$. stellatus population to grow in weight, faster than in basal length, basal width and height. There is also a tendency of basal length to grow faster than in basal width and height and basal width to grow faster than height.

Significant differences in growth patterns were, also, exhibited among study sites and between most of the biometric correlations. C. stellatus population in the sheltered site increased in weight relative to basal length and basal width significantly faster compared to the population in the exposed site. Furthermore, C. stellatus population in the sheltered site increased in basal length and basal width relative to height significantly faster compared to the population in the exposed site. The differences observed in the growth patterns could be attributed to the variable degree of exposure between sites, affecting barnacle density, since aggregation has been suggested to affect barnacle shape [24,25].

\subsection{Population Density}

According to [4], C. stellatus in the supra- and midlittoral rocky shores of the NW Mediterranean Sea forms characteristic belts that can reach densities of up to 30,000 individuals per square meter. The average $C$. stellatus density recorded in the present study was similar to densities recorded in the Eastern (Habonim, Israel) [20], Central (Eastern Ligurian, Italy) [37], and Western Mediterranean (Spain) [2]. However, higher population densities were recorded in the Western (France) [2] and Eastern Mediterranean (Turkey) [39]. In contrast, lower population densities were recorded in the Central (North Adriatic, Italy) [6] and Eastern Mediterranean (Chalkida, Thermaikos Gulf, Chalkidiki, Greece) [38] (Table 7).

Significantly higher abundance was exhibited at the exposed site (Site 1) compared to the sheltered (Site 2). C. stellatus is often more abundant on wave-exposed coasts than in sheltered situations [2,18], possibly as a result of higher food supply. Differences in the abundance between sites could also be attributed to suitable settlement substrata and micro-hydrodynamic and behavioral processes [84]. In several studies, small-scale variability of settlement (amongst sites, within sites) has been observed $[75,88,89]$. 
Table 7. Abundance of $C$. stellatus populations reported from various Mediterranean areas.

\begin{tabular}{ccc}
\hline Area & Average Density $\left(\mathbf{i n d} / \mathbf{m}^{\mathbf{2}}\right) \pm$ SE & References \\
\hline Italy Eastern Ligurian & $10,831 \pm 2527$ & {$[37]$} \\
Italy North Adriatic & 514 & {$[6]$} \\
Israel Habonim & $7618 \pm 628$ & {$[20]$} \\
Turkey Antalya Bay & $23,470 \pm 12,001$ & {$[39]$} \\
Spain Western Med & $8900 \pm 2510$ & {$[2]$} \\
France Western Med & $32,267 \pm 6834$ & {$[2]$} \\
Greece Chalkida & 1280 & {$[38]$} \\
Greece Thermaikos Gulf & 1773 & {$[38]$} \\
Greece Chalkidiki & 4594 & {$[38]$} \\
Greece Pagasitikos Gulf & $7868 \pm 557$ & Present study \\
\hline
\end{tabular}

Population density at the mid-shore level (lower-mid midlittoral zone) was significantly higher compared to the upper shore level (upper midlittoral zone-lower supralittoral fringe). Those differences could be attributed to higher larval supply and larval selection of preferable habitat, where food supply is higher and desiccation stress is lower $[14,90,91]$, resulting in higher settlement rate in the low shore. It has been suggested that post-settlement mortality may control adult barnacle abundance rather than settlement [13] and that desiccation pressure (despite exposure to wave splash) on shores along the Atlantic coasts of Spain, Portugal, and North Africa may inhibit the survival of C. stellatus [33].

A high level of similarity in the cover percentage of $C$. stellatus between levels was detected, with low similarity indicated between degrees of exposure and season. Two major groups were indicated: the upper shore-level group with $81 \%$ similarity and the lower shore-level group with $88 \%$ similarity. Extreme physical conditions, such as very high temperatures that prevail in the Eastern Mediterranean basin, can cause a high level of post-settlement mortality. Delany et al. [13] suggested that post-settlement mortality, rather than larval supply, determines the zonation patterns of the co-occurring chthamalids C. stellatus and C. montagui.

\subsection{Distribution Pattern}

Spatial point pattern analysis of C. stellatus populations indicated a significant clustered spatial dispersion pattern in the upper shore level of the sheltered site (Site 2) during autumn and spring. Similarly, a significant clustered spatial dispersion pattern was exhibited in the upper shore level of the exposed site (Site 1) and mid-shore level of the sheltered site in winter. Several factors often operating at microspatial scales, including competition, predation, habitat rugosity, wave exposure, desiccation, and local hydrographical regimes, may influence barnacle success at small spatial scales of individual shores and microhabitats $[19,31,32,34-36]$ and can potentially explain microhabitat distribution patterns. Barnacle settlements are also known to respond to small-scale heterogeneity of the substratum [26-29], created by the weathering of rocks as a result of natural processes (e.g., wave battering, water flow). Patterns of settlement at small spatial scales can be also attributed to larval behavior [92-96].

Identifying patterns of species distribution and the factors underlying these patterns is a fundamental goal in ecology. Barnacles have open populations with local recruitment, potentially uncoupled from local reproduction by a dispersal phase [97,98]. Considerable evidence has accumulated to indicate that mortality due to predation, competition, disturbance, or a combination of these three is important in structuring barnacle populations [35,36,99-101].

\subsection{Age Composition}

Barnes [102] reported a maximal longevity of four years for C. stellatus in Scotland and maximal length of $15 \mathrm{~mm}$, whereas in a laboratory study by Deevey [103], the maximal recorded life span was three years. In the present study six dominant age groups were identified with the dominant cohort in the third-year class, with roughly $45 \%$ of the total population (Table 6, Figure 12). According to Mieszkowska et al. [104] the chthamalid lifespan is greater than 10 years. Sexual maturity is obtained 
in the first year with a number of broods produced annually [104]. The Eastern Mediterranean (Mikhmoret, Israel) C. stellatus population exhibited a higher growth rate, attaining smaller size and longevity, in comparison with Atlantic populations [20].

Under predicted global warming scenarios, a $1.4-5.8^{\circ} \mathrm{C}$ rise in seawater temperature is expected over the next century [105]. Changes in the marine ecosystem that may accompany this warming could be of significant consequence to the functioning and diversity of marine ecosystems and may also have a considerable impact on the socioeconomic status of coastal communities that heavily rely on marine resources [106,107]. Rocky shore organisms could provide inexpensive and reliable indicators of alterations occurring in important components of the marine ecosystem [108]. It is therefore important to closely monitor changes in the coastal marine environment that could form a basis for predictive models allowing the real-time assessment of climatic impacts.

Author Contributions: Conceptualization, D.V.; methodology, D.V.; formal analysis, D.K.; investigation, D.V., Z.K., N.N., A.L., and D.K.; resources, D.V.; data curation, Z.K.; writing-original draft preparation, D.K., Z.K., N.N., A.L., and D.V.; writing-review and editing, D.V., D.K., Z.K., N.N., and A.L.; visualization, D.K.; supervision, D.V.; project administration, D.V.; funding acquisition, D.V. All authors have read and agreed to the published version of the manuscript.

Funding: This research received no external funding.

Conflicts of Interest: The authors declare no conflict of interest.

\section{References}

1. Stephenson, T.A.; Stephenson, A. Life Between Tidemarks on Rocky Shores; W.H. Freeman and Co.: San Francisco, CA, USA, 1972.

2. Crisp, D.J.; Southward, A.J.; Southward, E.C. On the distribution of the intertidal barnacles Chthamalus stellatus, Chthamalus montagui and Euraphia depressa. J. Mar. Biol. Assoc. UK 1981, 61, 359-380. [CrossRef]

3. Williams, G. Distribution of Chthamalus stellatus on the shores of North-East Ireland. Nature 1950, 166, 311. [CrossRef] [PubMed]

4. Pannacciulli, F.G.; Relini, G. The vertical distribution of Chthamalus montagui and Chthamalus stellatus (Crustacea, Cirripedia) in two areas of the NW Mediterranean Sea. Hydrobiologia 2000, 426, 105-112. [CrossRef]

5. Sousa, E.B.; Cruz, T.; Castro, J.J. Distribution and abundance of co-occurring chthamalid barnacles Chthamalus montagui and Chthamalus stellatus (Crustacea, Cirripedia) on the southwest coast of Portugal. Hydrobiologia 2000, 440, 339-345. [CrossRef]

6. Dolenc-Orbanić, N.; Battelli, C. The vertical distribution and abundance of Chthamalus stellatus Poli and Chthamalus montagui Southward (Crustacea, Cirripedia) at two localities of the Istrian peninsula coast (North Adriatic). Acta Adriat. 2017, 58. [CrossRef]

7. Southward, A.J. On the European species of Chthamalus (Cirripedia). Crustaceana 1964, 6, 241-254. [CrossRef]

8. Dando, P.R.; Crisp, A.J. Enzyme variation in Chthamalus stellatus and Chthamalus montagui (Crustacea: Cirripedia): Evidence for the presence of C. montagui in the Adriatic. J. Mar. Biol. Assoc. UK 1979, 59, 307-320. [CrossRef]

9. Anderson, D.T. Barnacles: Structure, Function, Development and Evolution; Chapman and Hall: London, UK, 1994; p. 357.

10. Ballantine, W.J. A biologically-defined exposure scale for the comparative description of rocky shores. Field Stud. 1961, 1, 1-19.

11. Southward, A.J. On the taxonomic status and distribution of Chthamalus stellatus (Cirripedia) in the north-east Atlantic region: With a key to the common intertidal barnacles of Britain. J. Mar. Biol. Assoc. UK 1976, 56, 1007-1028. [CrossRef]

12. Power, A.M. The Ecology of Chthamalid Barnacles: An Evaluation of Settlement and Recruitment in Regulating the Intertidal Distribution of Chthamalus Stellatus and C. Montagui in South-West Ireland. Ph.D. Thesis, National University of Ireland, Cork, Ireland, 2000.

13. Delany, J.; Myers, A.A.; McGrath, D.; O'Riordan, R.M.; Power, A.M. Role of post-settlement mortality and 'supply-side' ecology in setting patterns of intertidal distribution in the chthamalid barnacles Chthamalus montagui and C. stellatus. Mar. Ecol. Prog. Ser. 2003, 249, 207-214. [CrossRef] 
14. Jenkins, S.R. Larval habitat selection, not larval supply, determines settlement patterns and adult distribution in two chthamalid barnacles. J. Anim. Ecol. 2005, 74, 893-904. [CrossRef]

15. Shemesh, E.; Huchon, D.; Simon-Blecher, N.; Achituv, Y. The distribution and molecular diversity of the Eastern Atlantic and Mediterranean chthamalids (Crustacea, Cirripedia). Zool. Scr. 2009, 38, 365-378. [CrossRef]

16. Dando, P.R.; Southward, A.J. A new species of Chthamalus (Crustacea: Cirripedia) characterized by enzyme electrophoresis and shell morphology: With a revision of other species of Chthamalus from the western shores of the atlantic ocean. J. Mar. Biol. Assoc. UK 1980, 60, 787-831. [CrossRef]

17. Lavie, B.; Achituv, Y.; Nevo, E. The niche-width variation hypothesis reconfirmed: Validation by genetic diversity in the sessile intertidal cirripedes Chthamalus stellatus and Euraphia depressa (Crustacea, Chthamalidae). J. Zool. Syst. Evol. Res. 1993, 31, 110-118. [CrossRef]

18. Lipkin, Y.; Safriel, U. Intertidal zonation on Rocky Shores at Mikhmoret (Mediterranean, Israel). J. Ecol. 1971, 59, 1-30. [CrossRef]

19. O'Riordan, R.M.; Power, A.M.; Myers, A.A. Factors, at different scales, affecting the distribution of species of the genus Chthamalus Ranzani (Cirripedia, Balanomorpha, Chthamaloidea). J. Exp. Mar. Biol. Ecol. 2010, 392, 46-64. [CrossRef]

20. Guy-Haim, T.; Rilov, G.; Achituv, Y. Different settlement strategies explain intertidal zonation of barnacles in the Eastern Mediterranean. J. Exp. Mar. Biol. Ecol. 2015, 463, 125-134. [CrossRef]

21. Sanford, E.; Menge, B.A. Spatial and temporal variation in barnacle growth in a coastal upwelling system. Mar. Ecol. Prog. Ser. 2001, 209, 143-157. [CrossRef]

22. Benedetti-Cecchi, L.; Acunto, S.; Bulleri, F.; Cinelli, F. Population ecology of the barnacle Chthamalus stellatus in the northwest Mediterranean. Mar. Ecol. Prog. Ser. 2000, 198, 157-170. [CrossRef]

23. Bertness, M.D.; Gaines, S.D.; Yeh, S.M. Making mountains out of barnacles: The dynamics of acorn barnacle hummocking. Ecology 1998, 79, 1382-1394. [CrossRef]

24. Barnes, H.; Powell,H.T. The development, general morphology, and subsequent elimination of barnacle populations, Balanus crenatus and B. balanoides, after a heavy initial settlement. J. Anim. Ecol. 1950, 19, 175-179. [CrossRef]

25. Bertness, M.D. Intraspecific competition and facilitation in a northern acorn barnacle population. Ecology 1989, 70, 257-268. [CrossRef]

26. Crisp, D.J.; Barnes, H. The orientation and distribution of barnacles at settlement with particular reference to surface contour. J. Anim. Ecol. 1954, 23, 142-162. [CrossRef]

27. Hills, J.M.; Thomason, J.C. The effect of scales of surface roughness on the settlement of barnacle (Semibalanus balanoides) cyprids. Biofouling 1998, 12, 57-69. [CrossRef]

28. Herbert, R.J.H.; Hawkins, S.J. Effect of rock type on the recruitment and early mortality of the barnacle Chthamalus montagui. J. Exp. Mar. Biol. Ecol. 2006, 334, 96-108. [CrossRef]

29. Coombes, M.A.; La Marca, E.C.; Naylor, L.A.; Thompson, R.C. Getting into the groove: Opportunities to enhance the ecological value of hard coastal infrastructure using fine-scale surface textures. Ecol. Eng. 2015, 77, 314-323. [CrossRef]

30. Paine, R.T. Barnacle ecology: Is competition important? The forgotten roles of disturbance and predation. Paleobiology 1981, 7, 553-560. [CrossRef]

31. Menge, B.A.; Sutherland, J.P. Community regulation: Variation in disturbance, competition, and predation in relation to environmental stress and recruitment. Am. Nat. 1987, 130, 730-757. [CrossRef]

32. Southward, A.J. Note on the temperature tolerances of some intertidal animals in relation to environmental temperatures and geographical distribution. J. Mar. Biol. Assoc. UK 1958, 37, 49-66. [CrossRef]

33. Power, A.M.; Myers, A.A.; O'Riordan, R.M.; McGrath, D.; Delany, J. An investigation into rock surface wetness as a parameter contributing to the distribution of the intertidal barnacles Chthamalus stellatus and Chthamalus montagui. Estuar. Coast. Shelf Sci. 2001, 52, 349-356. [CrossRef]

34. Bertness, M.D.; Gaines, S.D.; Wahle, R.A. Wind-driven settlement patterns in the acorn barnacle Semibalanus balanoides. Mar. Ecol. Prog. Ser. 1996, 137, 103-110. [CrossRef]

35. Connell, J.H. The influence of interspecific competition and other factors on the distribution of the barnacle Chthamalus stellatus. Ecology 1961, 42, 710-723. [CrossRef]

36. Wethey, D.S. Sun and shade mediate competition in the barnacles Chthamalus and Semibalanus: A field experiment. Biol. Bull. 1984, 167, 176-185. [CrossRef] 
37. Canessa, M.; Bavestrello, G.; Bo, M.; Betti, F.; Gaggero, L.; Cattaneo-Vietti, R. The influence of the rock mineralogy on population density of Chthamalus (Crustacea: Cirripedia) in the Ligurian Sea (NW Mediterranean Sea). Eur. Zool. J. 2019, 86, 389-401. [CrossRef]

38. Kitsos, M. Contribution to the Study of the Biodiversity of the Midlittoral and Supralittoral Hard Substratum Assemblages. Ph.D. Thesis, University of Thessaloniki, Thessaloniki, Greece, 2003.

39. Beşir, C.; Çınar, M.E. Thoracic cirripeds (Thoracica: Cirripedia) from Antalya Bay (eastern Mediterranean). J. Black Sea/Mediterr. Environ. 2012, 18, 251-270.

40. Shkedy, Y.; Safriel, U.N.; Keasar, T. Life-history of Balanus amphitrite and Chthamalus stellatus recruited to settlement panels in the Mediterranean coast of Israel. Isr. J. Ecol. Evol. 1995, 41, 147-161. [CrossRef]

41. Vafidis, D.; Antoniadou, C.; Chintiroglou, C. Population dynamics, allometric relationships and reproductive status of Microcosmus sabatieri (Tunicata: Ascidiacea) in the Aegean Sea. J. Mar. Biol. Assoc. UK 2008, 88, 1043-1051. [CrossRef]

42. Antoniadou, C.; Vafidis, D. Population structure and morphometric relationships of Paracentrotus lividus (Echinodermata: Echinoidea) in the South Aegean Sea. Cah. Biol. Mar. 2009, 50, 293-301.

43. Kazanidis, G.; Antoniadou, C.; Lolas, A.P.; Neofitou, N.; Vafidis, D.; Chintiroglou, C.; Neofitou, C. Population dynamics and reproduction of Holothuria tubulosa (Holothuroidea: Echinodermata) in the Aegean Sea. J. Mar. Biol. Assoc. UK 2010, 90, 895-901. [CrossRef]

44. Vafidis, D.; Antoniadou, C.; Voultsiadou, E.; Chintiroglou, C. Population structure of the protected fan mussel Pinna nobilis in the south Aegean Sea (eastern Mediterranean). J. Mar. Biol. Assoc. UK 2014, 94, 787-796. [CrossRef]

45. Konstantinidis, I.; Gkafas, G.; Karamitros, G.; Lolas, A.; Antoniadou, C.; Vafidis, D.; Exadactylos, A. Population structure of two benthic species with different larval stages in the eastern Mediterranean Sea. J. Environ. Prot. Ecol. 2017, 18, 930-939.

46. Vafidis, D.; Antoniadou, C.; Ioannidi, V. Population density, size structure, and reproductive cycle of the comestible sea urchin Sphaerechinus granularis (Echinodermata: Echinoidea) in the Pagasitikos Gulf (Aegean Sea). Animals 2020, 10, 1506. [CrossRef] [PubMed]

47. Vafidis, D.; Drosou, I.; Dimitriou, K.; Klaoudatos, D. Population characteristics of the limpet Patella caerulea (Linnaeus, 1758) in Eastern Mediterranean (Central Greece). Water 2020, 12, 1186. [CrossRef]

48. Lolas, A.; Vafidis, D. Population dynamics of two caprellid species (Crustaceae: Amphipoda: Caprellidae) from shallow hard bottom assemblages. Mar. Biodivers. 2013, 43, 227-236. [CrossRef]

49. Lolas, A.; Antoniadou, C.; Vafidis, D. Spatial variation of molluscan fauna associated with Cystoseira assemblages from a semi-enclosed gulf in the Aegean Sea. Reg. Stud. Mar. Sci. 2018, 19, 17-24. [CrossRef]

50. Triantafyllou, G.; Petihakis, G.; Dounas, C.; Theodorou, A. Assessing marine ecosystem response to nutrient inputs. Mar. Pollut. Bull. 2001, 43, 175-186. [CrossRef]

51. Friligos, N. Eutrophication assessment in Greek coastal waters. Toxicol. Environ. Chem. 1987, 15, $185-196$. [CrossRef]

52. Korres, G.; Triantafyllou, G.; Petihakis, G.; Raitsos, D.E.; Hoteit, I.; Pollani, A.; Colella, S.; Tsiaras, K. A data assimilation tool for the Pagasitikos Gulf ecosystem dynamics: Methods and benefits. J. Mar. Syst. 2012, 94, S102-S117. [CrossRef]

53. Petihakis, G.; Triantafyllou, G.; Pollani, A.; Koliou, A.; Theodorou, A. Field data analysis and application of a complex water column biogeochemical model in different areas of a semi-enclosed basin: Towards the development of an ecosystem management tool. Mar. Environ. Res. 2005, 59, 493-518. [CrossRef]

54. Petihakis, G.; Triantafyllou, G.; Korres, G.; Pollani, A.; Theodorou, A. Ecosystem modeling: Towards the development of a management tool for a marine coastal system: Part I: General circulation, hydrological and dynamical structure. J. Mar. Syst. 2012, 94, S34-S48. [CrossRef]

55. Bakus, G.J. Quantitative Ecology and Marine Biology; AA Balkema: Rotterdam, The Netherlands, $1990 ;$ p. 157.

56. Abràmoff, M.D.; Magalhães, P.J.; Ram, S.J. Image processing with ImageJ. Biophotonics Int. 2004, 11, 36-42.

57. Underwood, A.J. Experiments in Ecology: Their Logical Design and Interpretation Using Analysis of Variance; Cambridge University Press: Cambridge, UK, 1997; p. 504.

58. Sneath, P.H.A.; Sokal, R.R. Numerical Taxonomy. The Principles and Practice of Numerical Classification; W.H. Freeman and Company: San Francisco, CA, USA, 1973; p. 573.

59. Bray, J.R.; Curtis, J.T. An ordination of the upland forest communities of Southern Wisconsin. Ecol. Monogr. 1957, 27, 326-349. [CrossRef] 
60. Clarke, K.R.; Gorley, R.; Somerfield, P.J.; Warwick, R. Change in Marine Communities: An Approach to Statistical Analysis and Interpretation, 3rd ed.; Primer-E Ltd.: Plymouth, UK, 2014.

61. Field, J.G.; Clarke, K.R.; Warwick, R.M. A practical strategy for analyzing multispecies distribution patterns. Mar. Ecol. Prog. Ser. 1982, 8, 37-52. [CrossRef]

62. Morisita, M. Measuring of the dispersion of individuals and analysis of the distributional patterns. Mem. Fac. Sci. Kyushu Univ. Ser. E Biol. 1959, 2, 215-235.

63. Elliott, J.M. Some Methods for the Statistical Analysis of Samples of Benthic Invertebrates, 2nd ed.; Freshwater Biological Association: Tolouse, France, 1977; p. 156.

64. Morisita, M. Io-Index, a measure of dispersion of individuals. Res. Popul. Ecol. 1962, 4, 1-7. [CrossRef]

65. Dale, M.R.T.; Dixon, P.; Fortin, M.-J.; Legendre, P.; Myers, D.E.; Rosenberg, M.S. Conceptual and mathematical relationships among methods for spatial analysis. Ecography 2002, 25, 558-577. [CrossRef]

66. Bhattacharya, C.G. A simple method of resolution of a distribution into Gaussian components. Biometrics 1967, 23, 115-135. [CrossRef]

67. Gayanilo, F.; Sparre, P.; Pauly, D. FAO-ICLARM Stock Assessment Tools II (FiSAT II) User's Guide; FAO: Rome, Italy, 2005; p. 168.

68. Lewis, J.R. The Ecology of Rocky Shores; English Universities Press: London, UK, 1964; p. 323.

69. Hartnoll, R.G.; Hawkins, S.J. Patchiness and fluctuations on moderately exposed rocky shores. Ophelia 1985, 24, 53-63. [CrossRef]

70. Jenkins, S.R.; Norton, T.A.; Hawkins, S.J. Settlement and post-settlement interactions between Semibalanus balanoides (L.) (Crustacea: Cirripedia) and three species of fucoid canopy algae. J. Exp. Mar. Biol. Ecol. 1999, 236, 49-67. [CrossRef]

71. Bellan-Santini, D.; Lacaze, J.-C.; Poizat, C.; Pérès, J.-M. Les Biocénoses Marines et Littorales de Méditerranée, Synthèse, Menaces et Perspectives; Muséum National d'Histoire Naturelle: Paris, France, 1994; p. 246.

72. Benedetti-Cecchi, L.; Menconi, M.; Cinelli, F. Pre-emption of the substratum and the maintenance of spatial pattern on a rocky shore in the northwest Mediterranean. Mar. Ecol. Prog. Ser. 1999, 181, 13-23. [CrossRef]

73. Pitacco, V.; MavriČ, B.; Orlando-Bonaca, M.; Lipej, L. Rocky macrozoobenthos mediolittoral community in the Gulf of Trieste (North Adriatic) along a gradient of hydromorphological modifications. Acta Adriat. 2013, 54, 67-85.

74. Caffey, H.M. Spatial and temporal variation in settlement and recruitment of intertidal barnacles. Ecol. Monogr. 1985, 55, 313-332. [CrossRef]

75. Gaines, S.; Roughgarden, J. Larval settlement rate: A leading determinant of structure in an ecological community of the marine intertidal zone. Proc. Natl. Acad. Sci. USA 1985, 82, 3707-3711. [CrossRef] [PubMed]

76. Menge, B.A. Relative importance of recruitment and other causes of variation in rocky intertidal community structure. J. Exp. Mar. Biol. Ecol. 1991, 146, 69-100. [CrossRef]

77. Crisp, D.J. Factors influencing growth-rate in Balanus balanoides. J. Anim. Ecol. 1960, 29, 95-116. [CrossRef]

78. Bertness, M.D.; Gaines, S.D.; Bermudez, D.; Sanford, E. Extreme spatial variation in the growth and reproductive output of the acorn barnacle Semibalanus balanoides. Mar. Ecol. Prog. Ser. 1991, 75, 91-100. [CrossRef]

79. Sanford, E.; Bermudez, D.; Bertness, M.D.; Gaines, S.D. Flow, food supply and acorn barnacle population dynamics. Mar. Ecol. Prog. Ser. 1994, 104, 49-62. [CrossRef]

80. Bustamante, R.H.; Branch, G.M.; Sean, E.; Robertson, B.; Peter, Z.; Michael, S.; Arthur, D.; Nick, H.; Derek, K.; Michelle, J.; et al. Gradients of intertidal productivity around the coast of South Africa and their relationships with consumer biomass. Oecologia 1995, 102, 189-201. [CrossRef]

81. Leonard, G.H.; Levine, J.M.; Schmidt, P.R.; Bertness, M.D. Flow-driven variation in intertidal community structure in a Maine estuary. Ecology 1998, 79, 1395-1411. [CrossRef]

82. Schmidt-Nielsen, K. Scaling: Why is Animal Size so Important? Cambridge University Press: Cambridge, UK, 1984; p. 252.

83. Brown, J.H.; Gillooly, J.F.; Allen, A.P.; Savage, V.M.; West, G.B. Toward a metabolic theory of ecology. Ecology 2004, 85, 1771-1789. [CrossRef]

84. Woodward, G.; Ebenman, B.; Emmerson, M.; Montoya, J.M.; Olesen, J.M.; Valido, A.; Warren, P.H. Body size in ecological networks. Trends Ecol. Evol. 2005, 20, 402-409. [CrossRef] [PubMed]

85. Leslie, H.M.; Breck, E.N.; Chan, F.; Lubchenco, J.; Menge, B.A. Barnacle reproductive hotspots linked to nearshore ocean conditions. Proc. Natl. Acad. Sci. USA 2005, 102, 10534-10539. [CrossRef] [PubMed]

86. Palmer, A.R. Predator size, prey size, and the scaling of vulnerability: Hatching gastropods vs. barnacles. Ecology 1990, 71, 759-775. [CrossRef] 
87. Safriel, U.N.; Erez, N.; Keasar, T. How do limpets maintain barnacle-free submerged artificial surfaces? Bull. Mar. Sci. 1994, 54, 17-23.

88. Pineda, J. Spatial and temporal patterns in barnacle settlement rate along a southern California rocky shore. Mar. Ecol. Prog. Ser. 1994, 107, 125-138. [CrossRef]

89. Denley, E.J.; Underwood, A.L. Experiments on factors influencing settlement, survival, and growth of two species of barnacles in new south wales. J. Exp. Mar. Biol. Ecol. 1979, 36, 269-293. [CrossRef]

90. Foster, B.A. Desiccation as a factor in the intertidal zonation of barnacles. Mar. Biol. 1971, 8, 12-29. [CrossRef]

91. Walters, L.J.; Wethey, D.S. Settlement and early post-settlement survival of sessile marine invertebrates on topographically complex surfaces: The importance of refuge dimensions and adult morphology. Mar. Ecol. Prog. Ser. 1996, 137, 161-171. [CrossRef]

92. Knight-Jones, E.W. Laboratory experiments on gregariousness during setting in Balanus balanoides and other barnacles. J. Exp. Biol. 1953, 30, 584-598.

93. Crisp, D.J. Territorial behaviour in barnacle settlement. J. Exp. Biol. 1961, 38, 429-446.

94. Crisp, D.J. Gregariousness and systematic affinity in some North Carolinian barnacles. Bull. Mar. Sci. 1990, 47, 516-525.

95. Raimondi, P.T. Patterns, mechanisms, consequences of variability in settlement and recruitment of an intertidal barnacle. Ecol. Monogr. 1990, 60, 283-309. [CrossRef]

96. Schubart, C.D.; Basch, L.V.; Miyasato, G. Recruitment of Balanus glandula Darwin (Crustacea: Cirripedia) into empty barnacle tests and its ecological consequences. J. Exp. Mar. Biol. Ecol. 1995, 186, 143-181. [CrossRef]

97. Roughgarden, J.; Iwasa, Y.; Baxter, C. Demographic theory for an open marine population with space-limited recruitment. Ecology 1985, 66, 54-67. [CrossRef]

98. Hughes, T.P. Recruitment limitation, mortality, and population regulation in open systems: A case study. Ecology 1990, 71, 12-20. [CrossRef]

99. Connell, J.H. Effects of competition, predation by Thais lapillus, and other factors on natural populations of the barnacle balanus balanoides. Ecol. Monogr. 1961, 31, 61-104. [CrossRef]

100. Menge, B.A. Recruitment vs. post recruitment processes as determinants of barnacle population abundance. Ecol. Monogr. 2000, 70, 265-288. [CrossRef]

101. Carroll, M.L. Barnacle population dynamics and recruitment regulation in southcentral Alaska. J. Exp. Mar. Biol. Ecol. 1996, 199, 285-302. [CrossRef]

102. Barnes, H. The growth rate of Chthamalus stellatus (Poli). J. Mar. Biol. Assoc. UK 1956, 35, 355-361. [CrossRef]

103. Deevey, E.S. Life tables for natural populations of animals. Q. Rev. Biol. 1947, 22, 283-314. [CrossRef]

104. Mieszkowska, N.; Burrows, M.T.; Pannacciulli, F.G.; Hawkins, S.J. Multidecadal signals within co-occurring intertidal barnacles Semibalanus balanoides and Chthamalus spp. linked to the Atlantic Multidecadal Oscillation. J. Mar. Syst. 2014, 133, 70-76. [CrossRef]

105. Schneider, S.H. What is 'dangerous' climate change? Nature 2001, 411, 17-19. [CrossRef] [PubMed]

106. Southward, A.J.; Boalch, G. The marine resources of Devon's coastal waters. New Marit. Hist. Devon 1992, 1, 61-71.

107. Southward, A.J.; Boalch, G. The effect of changing climate on marine life: Past events and future predictions. Exeter Marit. Stud. 1994, 9, 101-143.

108. Southward, A.J.; Hawkins, S.J.; Burrows, M.T. Seventy years' observations of changes in distribution and abundance of zooplankton and intertidal organisms in the western English Channel in relation to rising sea temperature. J. Therm. Biol. 1995, 20, 127-155. [CrossRef]

Publisher's Note: MDPI stays neutral with regard to jurisdictional claims in published maps and institutional affiliations.

(C) 2020 by the authors. Licensee MDPI, Basel, Switzerland. This article is an open access article distributed under the terms and conditions of the Creative Commons Attribution (CC BY) license (http://creativecommons.org/licenses/by/4.0/). 